\title{
La situación del trabajo infantil y su relación con las políticas públicas e intervención social en Argentina y Chile ${ }^{1}$
}

\author{
María Inés Peralta*, Carolina Muñoz ${ }^{* *}$
}

\begin{abstract}
Resumen
El presente artículo realiza un análisis comparativo de la situación del trabajo infantil y su relación con las políticas públicas e intervención social en Argentina y Chile considerando el fenómeno, sus relaciones y dimensiones como problemática política y social.
\end{abstract}

\section{Palabras clave \\ Políticas Públicas, intervención social, trabajo infantil.}

\section{Abstract}

The present article presents a comparative analysis of the situation of child work and his relation with the public policies and social intervention in Argentina and Chile considering the phenomenon, his relations and dimensions like political and social problems.

\section{Key words}

Public policies, social intervention, child work.

\section{Presentación}

T a realidad de la infancia es una preocupación permanente de los Estados a nivel mundial, especialmente en América Latina, donde las situaciones de vulneración se profundizan con los desiguales niveles de crecimiento y los procesos de modernización en curso en la región.

Los esfuerzos realizados por los países latinoamericanos, en conjunto con diversos organismos internacionales, han permitido generar condiciones cada vez más garantistas para la infancia, Sin embargo, la situación específica referida al ámbito laboral e infancia es un tema aún no regulado de manera clara y explícita, especialmente en los países del Cono Sur. Si bien se reconoce como fenómeno creciente, la precarización laboral y el amplio desempleo impiden abordarlo de una manera drástica. Los diversos factores asociados, así como la complejidad de la estructura social latinoamericana y la falta de voluntad política, 
son algunos elementos que nos permiten visualizar la constitución de una problemática que supera ampliamente el tema de la vulneración de derechos e incide directamente en la fuerza laboral existente en un país para su desarrollo económico.

Cabe preguntarse, entonces, cómo establecer prioridades al momento de enfrentar las relaciones entre infancia y trabajo: ¿Problema social, problema económico, déficit educacional? Sus múltiples dimensiones nos enfrentan también a variadas interpretaciones del fenómeno, desde los abolicionistas absolutos de cualquier forma de trabajo infantil hasta quienes abogan por su regulación para una adecuada inserción en el mercado laboral.

Pero tal vez la preocupación principal, indistintamente de las posturas existentes, debe apuntar a generar conocimientos acabados de la magnitud del problema. Sus relaciones, el contexto cultural y social en que se manifiesta y las cifras manejables en cada uno de los países, de manera de poder generar estrategias para enfrentarlo. El gran escollo que encontramos hoy es el desconocimiento en torno a la naturaleza del fenómeno y la dimensión que este alcanza. Si revisamos la realidad latinoamericana, aparecen cifras ambiguas y una caracterización general, sin embargo, no existe información concreta que nos permita abordar la problemática.

Así, hoy se nos presenta el imperativo de "conocer" el fenómeno, sus relaciones y dimensiones para establecer si es una problemática para nuestros países y cómo enfrentarlo generando estrategias desde lo social, lo político y lo económico de manera democrática y responsable.

Enfrentados a este desafío, las escuelas de Trabajo Social de la Universidad Nacional de Córdoba, Argentina, y la Universidad Alberto Hurtado de Chile, desarrollaron una investigación con la finalidad de dar cuenta de los contextos en los que se produce el Trabajo infantil, las tensiones que emanan de las políticas destinadas a erradicarlo y sus prácticas.

\section{Convivencia de paradigmas sobre la infancia y la adolescencia}

\section{El paradigma de la Situación Irregular}

Tanto en Chile como en Argentina -y podríamos decir en toda América Latina- la cultura filantrópica y caritativa del siglo XIX logró la emergencia social y la conformación en la opinión publica de preocupación por la situación desgarradora de la infancia. Esta mirada en los hechos fue funcional y compatible a las ideas de la fragilidad e inmadurez del niño/a y creó la necesidad de control por parte del adulto; consiguió que se legislara sobre la infancia desde sus dos modelos: higienistas-preventivos y represivos.

Dentro de este paradigma, se levantan en Chile y Argentina legislaciones que perduraron hasta fines del siglo XX. En el trasfondo del marco jurídico desarrollado, se asimila al niño/a abandonado, maltratado, con conductas extralegales o en conflicto con la ley penal.

Sin hablar de forma explícita del trabajo infantil, en las primeras legislaciones en ambos países, se establece que se entenderá por abandono material o moral, o peligro moral, cuando los padres, tutores o guardadores, inicien a los menores de 18 años, que estén bajo su cuidado, en actividades que sean perniciosas para su salud y desarrollo. En ese marco, las actividades asociadas al trabajo eran penadas. No obstante esta penalización, en paralelo, el trabajo infantil aparece invisibilizado en las propuestas de los programas sociales de la época, donde el trabajo de los niños/as aparece como factor "preventivo" de la delincuencia y se realizaba en instituciones de menores y talleres agrícolas e industriales (Larrandart-1989)

En efecto, los niños/as y, más aun, los adolescentes institucionalizados eran entregados a "casas de familias” para realizar tareas de jardinería y mandaderos, para los varones o servicio doméstico y cuidados de niños en el caso de las mujeres, 
a cambio de que la familia se hiciera cargo de la educación. Lucila Larrandart hace referencia, en un trabajo sobre la historia de la infancia en Argentina, a las transformaciones que operan en el discurso sobre infancia: desde el discurso caritativo al de la tutela y, finalmente, cómo desemboca en el de la alarma social. Situación similar ocurría en Chile en la misma época.

En síntesis, aparece la existencia de una contradicción funcional al sistema: se criticaba a los padres que permitían el trabajo de sus hijos en la calle, pero el mismo era permitido en las instituciones de menores, bajo un criterio preventivo para socializar a los futuros posibles delincuentes a través de su disciplinamiento como fuerza laboral. En lo concreto, estos niños/as y adolescentes constituían mano de obra barata para casas de familias de sectores de clase media y alta.

Esta situación es reflejo de la historia de la infancia en América Latina, que ha sido una historia de control, oscilando entre la protección y la represión (García Méndez, 1997). Tanto en Chile como en Argentina, la legislación y servicios sociales para la infancia, se enmarcaron básicamente bajo el concepto de la "desviación social”, es decir, niños/as que estaban fuera de la norma: vagos, pordioseros, explotados sexualmente, abandonados, etcétera. Estas conductas o condiciones fueron definidas como riesgo material o moral, y se situaron bajo la Doctrina de la Irregularidad Social.

Esta Doctrina es hereditaria del Sistema Especial Judicial y Correccional implementado en Estados Unidos, fundado en el movimiento llamado "child savers". Tanto en Chile como en Argentina, se instaló un sistema de control, prevención y tratamiento para combatir aquello que se concebía como “desviación social” a través de la poderosa figura del Juez de Menores. Las estrategias de apoyo diseñadas para los niños/as definidos "en riesgo" eran aplicadas tanto a niños/as en necesidad de protección, como a aquellos que eran infractores de ley. La orientación de estas estrategias era bá- sicamente la de traspasar el rol de cuidado de los padres a organismos estatales o colaboradores de éste, reemplazando el rol parental, en una marcada institucionalización de los niños/as, cuando sus familias eran definidas como disfuncionales.

Esta forma de prestación de servicios, orientó los servicios sociales para la infancia en Chile y Argentina por todo el siglo XX y sólo se ha tratado de modificar en la última década. Pilotti (2000: 18) establece que, en el dominio del discurso de la irregularidad social, el rol del estado fue definido como "Pater Patrie" para supervisar el rol parental y su responsabilidad de satisfacer las necesidades básicas de los niños/as.

Danzelot (1976) ha señalado que una de las consecuencias más negativas de esta concepción fue el estigma asociado a las familias que entran en el circuito de los servicios sociales, ya que el sólo hecho de ser usuarios de éstos los convertía en fracasados en cumplir su tarea parental y familiar y los definía como anómalos. Las consecuencias de este paradigma han sido particularmente fuertes en nuestros países en los periodos de dictadura militar, donde se otorgó un amplio poder el Juez de menores en un modelo Tutelar. Se prestó el mismo tipo de servicios a niños/as vulnerados y niños/as infractores de la ley y los servicios sociales fueron transferidos al sector privado.

García Méndez ha afirmado que, en América Latina, la perspectiva de "los salvadores de los niños” influenció la forma de entender y tratar los problemas de los niños/as en el sentido de poner el acento en las conductas desviadas de las normas sociales que, supuestamente, eran aceptadas por la mayoría de la sociedad. Hasta 1940, ideas bioantropológicas y psicológicas prevalecieron para validar la segregación de los niños/as y usar un modelo médico para tratarlos. Al final de los años '40, este modelo médico entró en crisis y se privilegió una visión funcionalista de la sociedad, donde se asumía el carácter correccional de los servicios sociales y la segregación e institucionalización se 
reconocían como mecanismos incuestionables para defender a la sociedad y proteger a los niños/as abandonados y delincuentes. (García Méndez, 1997: 3-4).

En el contexto del advenimiento de la democracia, en ambos países, y el compromiso que los nuevos gobiernos adquieren con la Convención Internacional de Derechos del Niño, emerge la necesidad de transformar los servicios sociales para niños y niñas y sus familias, bajo la influencia normativa de nuevos principios orientando las políticas sociales. En este escenario, no podemos dejar de evidenciar las resistencias institucionales, culturales y sociales de quienes interpretan la realidad social de los niños/as bajo la influencia del antiguo paradigma de la Irregularidad Social.

\section{El paradigma de la protección integral}

La Doctrina de la Protección Integral tiene, como documento fundamental, la Convención Internacional de los Derechos del Niño (CDN), documento elaborado por expertos y organizaciones de adultos en defensa de la Infancia.

Después de 200 años de la Declaración Universal de los Derechos Humanos, como fruto de la Revolución Francesa, se logra que casi todos los países de mundo reconozcan a los niños y niñas como sujetos de derechos.

La CDN entrega los fundamentos a esta nueva Doctrina de la Protección Integral, representando un punto de quiebre en la posición de los niños/as en su relación con la ley, la familia, la comunidad y el gobierno. Los niños/as ahora son considerados sujetos de derecho en lugar de objetos de intervención.

La CDN está basada en una propuesta legal y cultural, la cual considera a los niños/as como personas progresivamente autónomos, quienes son protagonistas, creativos, y tienen intereses y preferencias particulares. Son personas responsables y capaces de considerar y respetar los derechos de otros. Este nuevo paradigma que guía los servicios sociales debe proveer un sistema de protección integral, configurar un nuevo tipo de visión sobre los niños/as donde se reconozca el derecho que tienen a una vida en familia, a ejercitar sus derechos dentro de ella y a recibir apoyo subsidiario del gobierno.

En este nuevo sistema, el gobierno interviene en dos formas: protegiendo a los niños/as de las violaciones a sus derechos y haciendo efectiva la responsabilidad que ellos tienen cuando infringen la ley, respetando las garantías y el derecho al justo proceso.

Hoy los servicios sociales para niños/as y familias están siendo desafiados por estos nuevos principios que orientan la política nacional. El discurso de Derecho ha influido las orientaciones de la política y la retórica pública, pero esta influencias parecen marginales cuando son medidas a través de la observación directa de los servicios que efectivamente se le ofrecen a los niños/as y sus familias (Farías, 2004).

Esta distancia entre prácticas institucionales y el discurso público se puede entender al examinar la realidad de la infancia social en América Latina bajo un tercer paradigma que podríamos llamar la tercera vía.

Esto es particularmente importante ya que el caso que nos ocupa, el del niño trabajador, no es explicitado claramente en la CDN. En su artículo N ${ }^{\circ}$ 32. inciso1 dice: "Los estados partes reconocen el derecho del niño a estar protegido contra la explotación económica y contra el desempeño de cualquier trabajo que pueda ser peligroso o entorpecer su educación o que sea nocivo para su salud y su desarrollo físico, mental, espiritual y social” y en el inciso 3 exige medidas que garanticen la protección. El artículo tiene una posición ambigua ya que no fomenta la erradicación del trabajo infantil, pero tampoco lo reconoce como derecho.

UNICEF, como institución de Naciones Unidas para la defensa de la infancia, es la organización por antonomasia que se ha encargado del desarro- 
llo de la doctrina de la Protección Integral y de que los países que la firmaron adopten políticas acordes hacia la infancia y de la transmisión de la Convención, el monitoreo de su cumplimiento y la difusión e interpretación de sus postulados.

Con respecto a los niños/as que trabajan en espacios públicos como las calles de las grandes urbes, se ha acuñado la expresión "niños en situación de calle”, en "circunstancias difíciles" o desarrollando "estrategias de sobrevivencia” con grave riesgo para su salud física y mental. Al haber adoptado este término -estrategias de sobrevivencia- se estaría reconociendo que hay diversos tipos de tareas que realizan niñas y niños y que algunas de ellas no pueden ser catalogadas como "formas de explotación” y que reclaman otro tipo de consideración, por estar asociadas a contextos sociales o culturales particulares. En el caso de nuestras sociedades con altos índices de pobreza, la participación de niños y niñas en trabajos que significan un aporte económico a sus familias impuso una consideración particular, pero manteniéndose la resistencia a definirlo como trabajo.

La UNICEF habla de "prevenir el trabajo infantil” y describe las "peores formas del trabajo infantil, como aquel realizado en minas, servidumbre, prostitución, manejo de maquinaria peligrosa y otras actividades ilícitas. En estas formas estarían implicados, según la directora de la institución, el 73 \% de los 240 millones de niños entre 5 y 17 años que trabajan en el mundo". Lo anterior demuestra el esfuerzo por identificar, cuantificar y precisar las peores formas de trabajo infantil que se propone erradicar.

\section{La tercera vía: El paradigma de la promoción social de la infancia}

Este paradigma reconoce la Convención Internacional de los Derechos del Niño como un avance significativo, pero sostiene que la historia de la infancia es la historia de su control y, por eso, apunta a una nueva cultura de la infancia, donde su historia empiece a ser la del protagonismo organizado y colectivo. Donde el niño se desarrolle como sujeto económico y social, como actor político y en plenitud de ciudadanía.

Este paradigma propone la constitución autónoma de un movimiento mundial de niños/as trabajadores con autodeterminación y el acompañamiento respetuoso de los adultos a este proceso. Esta construcción del colectivo de infancia se asienta en la organización de niñas y niños trabajadores y se distingue de la concepción liberal que reduce el protagonismo a una promoción personalista, entendida como libertad individual sin responsabilidad social. La constitución de otra cultura de la infancia es una lucha germinal de carácter cultural social y política, llevada adelante por el dinamismo de los movimientos de niños/as. Ello implica transformar el adultocentrismo a partir de una reivindicación histórica, generacional, de género y de clase.

Esta concepción es detentada por los Movimientos de NATs ${ }^{2}$ que surgen en Perú y se extienden a otros países latinoamericanos, y a otros continentes, especialmente del $3^{\circ}$ mundo como Asia y Africa. En Perú, desde hace casi 30 años, se ha creado un instituto llamado IFEJANT ${ }^{3}$ que promueve la existencia, articulación y argumentación de este paradigma.

El reconocimiento y la dignificación del trabajo de los niños/as es un eje central que sustenta este paradigma a través de prácticas sociales y desarrollos teóricos denominados "la valoración crítica" del trabajo infantil, cuyos argumentos principales se intentará resumir a continuación: ${ }^{4}$

La valoración se refiere al ejercicio de un derecho universal y al valor de humanización que tiene el trabajo, tanto en la subjetividad como en la inte-

2 NATs Niños y adolescentes trabajadores.

3 IFEJANT Instituto de formación de educadores de Niños y adolescentes trabajadores.

4 Estas argumentaciones han sido extraídas de materiales publicados por el IFEJANT cuyos autores son Schibiotti, Giangi, Cuassianovich, Alejandro, Bazán, Juan y Liebel, Manfred, consignados en la bibliografía y también se han utilizado expresiones de documentos públicos elaborados en los Encuentros Internacionales de Niños y Adolescentes Trabajadores. 
gración social. Por su parte, la crítica se refiere a las condiciones en que se da el trabajo infantil en el modelo neoliberal globalizado y a no reducir el ser humano al trabajo.

Se asume una concepción dialéctica del trabajo infantil, señalando la tensión entre la explotación y las condiciones adversas en que ejercen el trabajo los niños (y también los adultos) en el capitalismo. Por otro lado, se considera que se recupera el sentido de lucha por la vida, de inclusión social, de proyecto, de identidad y esperanza de salir de la pobreza que este tiene para ellos. La valoración crítica es, a la vez, una recuperación de la potencialidad ética, creadora y movilizadora del trabajo humano y una denuncia a la forma instrumental y mercantilizada que el trabajo ha adquirido en la sociedad capitalista. Esta concepción sostiene que no se puede educar a los niños/as en la contradicción de considerar el trabajo naturalmente malo y negativo hasta los 18 años y después valorarlo positivamente y obligarlos a trabajar para vivir.

Este paradigma propone que lo que hay que abolir no es el trabajo de niños/as y adolescentes, sino la explotación de su trabajo. Además, sostienen que valorar críticamente el trabajo infantil, no significa valorar los explotadores o los trabajos marginales, sino mirar al niño/a en su subjetividad y la potencialidad que despliega en la salida laboral. Ello implica reconocer, en el trabajo, una herramienta de construcción de autoestima, de identidad, de esfuerzos por una educación adecuada a su realidad, de organización, pertenencia a un colectivo, de actoría social y lucha por sus derechos, a partir de su visibilidad histórica.

La crítica al paradigma anterior se asienta en que aquel pretenderá construir una sociedad solamente desde la normativa jurídica, sin escuchar a los niños reales ${ }^{5}$, y no hay sociedad humanizada que se pueda construir sin amor y sin revisión del poder.

5 Los niños/as y adolescentes representantes de le Movimiento de NATs en varias oportunidades han sido subestimados, no escuchados o expulsados de las cumbres sobre la infancia o las reuniones internacionales de la OIT, bajo el pretexto de que son "niños manipulados."
En síntesis, la convivencia de paradigmas se expresa en las prácticas sociales y en las instituciones por las que circulan niños/as y adolescentes. El primer paradigma -de la situación irregular- se puede decir que ya está siendo superado desde el discurso institucionalizado, aunque no desde las prácticas instaladas y naturalizadas. Los otros dos paradigmas están en debate, y el desafío es que sean de los derechos de la infancia, lo que sostenga la discusión. Lo que insta a desarrollar aún más la capacidad de escucha hacia niños/as y adolescentes y de reconstrucción de nuestras propias instituciones, en tanto formaciones socioculturales.

En virtud de lo señalado anteriormente, surge la necesidad de conocer y contextualizar el fenómeno del trabajo infantil en ambos países, y de develar las tensiones que emanan de un discurso que, si bien se enmarca en una perspectiva de derecho, se entrecruza con lógicas instauradas por más de un siglo en los servicios sociales, sus usuarios y la sociedad en su conjunto. Para ello, nos hemos propuesto como objetivo: “Analizar la situación del trabajo infantil desde el año 2000 hasta la actualidad, en dos países del Cono Sur, y la relación existente entre políticas públicas, los programas sociales implementados y realidad social en cada país.

\section{Acerca de la metodología empleada}

Esta investigación apunta a realizar un análisis de caso, a base del enfoque de Análisis de discursos. "El análisis de discurso crítico busca conocer las estructuras, estrategias u otras propiedades del texto, el lenguaje, la interacción verbal o eventos comunicativos que juegan un rol en los modos de reproducción” (van Dijk,1993:250)

En esta lógica, nos interesa entender el Discurso como un "grupo de afirmaciones que entregan un lenguaje para hablar sobre las cosas. Una forma de representar el conocimiento acerca de un tema particular en un momento histórico determinado... el discurso se refiere a la producción de conocimiento 
a través del lenguaje” (Foucault in Hall, 1992:291 in Hall, 1997:44).

Esto nos permitirá analizar las estrategias, el sentido e influencia que éstas pueden tener para los sujetos de intervención, ya que “todas las prácticas implican un significado, y los significados moldean e influencian lo que hacemos -nuestra conductatodas las prácticas tienen un aspecto discursivo" (Foucault in Hall,1992:291 in Hall,1997:44).

Para realizar dicho análisis, se revisó el material producido en los últimos seis años referente a la situación del Trabajo Infantil en Argentina y Chile, ya sea por organismos estatales o de cooperación nacionales e internacionales. Además de revisar las políticas públicas vigentes en los dos países, los marcos jurídicos regulatorios y la presencia de la temática en el discurso estatal. Finalmente, se identificaron las propuestas de intervención social, en Argentina y Chile, correspondientes al período 2000-2004.

Al mismo tiempo, se llevó a cabo una revisión analítica de material escrito; entrevistas semi-estructuradas a informantes clave, correspondientes a tres profesionales del ámbito social insertos en organismos estatales y/o internacionales y agencias que se encuentran implementando programas de reducción del Trabajo Infantil. Finalmente, se realizó un grupo focal con un equipo de intervención psico-social en Trabajo Infantil.

Cada una de éstas técnicas fue aplicada primero en cada uno de los países y luego se analizó la información recopilada, por el equipo de investigadores.

\section{Trabajo infantil: contexto y discurso público}

En Chile, el Trabajo Infantil es un fenómeno social declarado preocupación de la política pública, en el marco de las convenciones internacionales ratificadas por Chile a partir de 1990 y de la preocu- pación progresiva de organismos internacionales y privados que lo condenan como una "práctica que desvaloriza y vulnera los derechos del niño a la educación, la protección, el descanso, recreación y cultura, al desarrollo físico y mental, entre otros derechos” (Ferrari, 2001:.8).

Chile ratificó el año 1990 la Convención Internacional sobre los Derechos del Niño (CDN), aprobada por la Asamblea General de las Naciones Unidas, el 20 de noviembre de 1989. En ella, los Estados se comprometen a tomar medidas tendientes a brindar condiciones para el ejercicio de los derechos a la protección, la provisión y la participación de niños, niñas y adolescentes.

En el tema del trabajo infantil, la Convención plantea en su artículo 32 el derecho del niño a "estar protegido contra la explotación económica y contra el desempeño de cualquier trabajo que pueda ser peligroso o entorpecer su educación o que sea nocivo para su salud o para su desarrollo físico, mental, espiritual, moral o social”.

Compromete, además, a los Estados a adoptar medidas legislativas, administrativas, sociales y educacionales, para garantizar la aplicación de este artículo. Dentro de ellas establece: fijar una edad mínima para trabajar, reglamentación de horario y condiciones de trabajo y sanciones apropiadas para el incumplimiento de ello.

El Derecho a la Educación es protegido también en la CDN, habitualmente vulnerado en situaciones de explotación laboral:

Artículo 28 "Los Estados Partes reconocen el derecho del niño a la Educación y, a fin de que se pueda ejercer progresivamente y en condiciones de igualdad de oportunidades ese derecho deberán,” entre otros:

- "Implantar la enseñanza primaria obligatoria y gratuita para todos.”

- "Fomentar el desarrollo en sus distintas for-

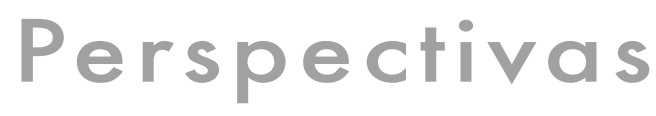


mas, de la enseñanza secundaria, incluida la enseñanza general y profesional; hacer que todos los niños dispongan de ella y tengan acceso a ella y adoptar medidas apropiadas tales como la implantación de la enseñanza gratuita y la concesión de asistencia financiera en caso de necesidad.”

La Convención advierte también, en su artículo 39, la necesidad de posibilitar la recuperación y reintegración social de niños/as y adolescentes vulnerados en sus derechos por situaciones de explotación.

Por otra parte, la Organización Internacional del Trabajo (OIT) ha incluido el trabajo infantil entre sus preocupaciones fundamentales: "El principal instrumento de OIT en su lucha por abolir el trabajo infantil han sido, y siguen siendo, las normas del trabajo que determinan el concepto de una edad mínima para ingresar en el empleo. Este criterio responde a dos deseos: el de proteger a los niños respecto de un trabajo que interfiera con su pleno desarrollo y la búsqueda de una eficiencia económica mediante mercados de trabajo de adultos que funcionen correctamente.”(OIT, 2002)

Al respecto, la OIT aprobó los convenios 138 (1973) y 182 (1999). Nuestro país ratificó el primero en 1999. El cuadro siguiente grafica los compromisos jurídicos adquiridos en los últimos años: 
Compromisos Internacionales

1919-1921: Se ratifican siete convenios de la Organización Internacional del Trabajo (OIT) referidos al trabajo infantil. Estos son: Convenios 5 y 6 de 1919, sobre edad mínima de admisión a trabajos industriales y horario nocturno; Convenio 7 de 1920, sobre edad mínima en el trabajo marítimo; Convenios 10, 15 y 16 de 1921, referidos a exigencias de edad mínima en el trabajo agrícola, de pañoleros y fogoneros, y examen médico obligatorio de menores de edad empleados a bordo de buques, respectivamente.

1989: Se ratifica el Pacto Internacional de Derechos Económicos, Sociales y Culturales, que expresamente establece la protección a los niños, niñas y adolescentes contra la explotación económica y social.

1990: Se ratifica la Convención de Derechos del Niño de Naciones Unidas, que reconoce el derecho de los niños y niñas a estar protegidos contra cualquier forma de explotación económica y contra el desempeño de cualquier trabajo que pueda ser peligroso para su desarrollo físico, mental, espiritual, moral o social (Art. 32, Nº1).

1999: Se ratifica el Convenio 138 de la OIT, por el que los Estados se comprometen a seguir una política nacional para asegurar la abolición efectiva del trabajo infantil y elevar progresivamente la edad mínima de admisión del empleo.

2000: Se ratifica el Convenio 182 de la OIT sobre las peores formas del trabajo infantil, referido a la acción inmediata para su prohibición y eliminación, como también a la protección contra todas las formas de explotación dañinas y perjudiciales al bienestar infantil y adolescente.

2003: El Congreso aprueba el Protocolo Opcional de la Convención de los Derechos del niño relativo a la venta, la prostitución y la utilización de niños en la pornografía. Dicho protocolo impone obligaciones a los Estados en el castigo de esos ilícitos y en la reparación de las víctimas.

\section{Compromisos Nacionales}

1996: Se firma un Memorando de Entendimiento entre el Programa IPEC/OIT y el Ministerio del Trabajo y Previsión Social.

Agosto 1996: Por Decreto Presidencial, se constituye el Comité Nacional para la Erradicación del Trabajo Infantil y la Protección del Menor Trabajador, en la actualidad el Comité Nacional Asesor para la Prevención y Erradicación Progresiva del Trabajo Infantil (en adelante, el Comité Nacional). En éste participan representantes de diferentes organismos de Gobierno, de organizaciones sociales, de empleadores y trabajadores y de organizaciones internacionales.

1999: Se elabora el Marco para la Acción contra la Explotación Sexual Comercial Infantil.

2001: Se difunde la Política y Plan de Acción Integrado para la Infancia y la Adolescencia. Este instrumento constituye un marco ético y político orientador en materia de las políticas de infancia y de las acciones desarrolladas por el conjunto del Estado

2000: Se aprueba en el Senado la Ley $\mathrm{N}^{0} 19.684$ que modifica el Código del Trabajo, elevando la edad mínima de admisión al empleo de 14 a 15 años, respondiendo así a los estándares del Convenio 138 de la OIT.

2000-2001: El Comité Nacional elabora y publica un Plan de Prevención y Erradicación Progresiva del Trabajo Infantil y Adolescente en Chile 2001-2010.

2002: Se extiende el Memorando de Entendimiento suscrito en 1996, confirmando el compromiso de Chile en la lucha por la erradicación del trabajo infantil.

2003: Se terminan de constituir en la totalidad de las regiones los Comités Regionales para la Prevención y Erradicación Progresiva del Trabajo Infantil.

2002-2004: La OIT y el Ministerio del Trabajo y Previsión Social llevan a cabo el proyecto "Diagnóstico Nacional del Trabajo Infantil y Adolescente e Identificación de sus Peores Formas”, con apoyo del Servicio Nacional de Menores (SENAME) y el Instituto Nacional de Estadísticas (INE). 
Estas ratificaciones han significado esfuerzos por aumentar progresivamente la edad de incorporación de los niños/as al mundo laboral. Además, las acciones gubernamentales en este tema han implicado que:

- $\quad$ En el año 1996 se crea, bajo la coordinación del Ministerio del Trabajo, el "Comité Nacional Asesor para la Erradicación del Trabajo Infantil y Protección del Menor Trabajador", actualmente denominado "Comité Nacional Asesor para la Prevención y Erradicación Progresiva del Trabajo Infantil”.

- $\quad$ Este comité diseñó el "Plan Nacional para la Prevención y Erradicación del Trabajo Infantil y Adolescente en Chile” y es responsable de la implementación de acciones y del seguimiento de los resultados obtenidos en el período 2001 a $2010 .^{6}$

- $\quad$ Entre el año 2002 y el 2004 el Plan Nacional llevó a cabo la implementación del proyecto "Diagnóstico Nacional del Trabajo Infantil e Identificación y Sistema de Registro de sus Peores Formas”. Esta fue una iniciativa conjunta del Ministerio del Trabajo, el Instituto Nacional de Estadísticas y el Servicio Nacional de Menores, con el apoyo de IPEC/OIT. ${ }^{7}$

Los resultados de estos diagnósticos y registros son los siguientes:

- $\quad 196.000$ niños, niñas y adolescentes entre 5 y 17 años trabajan para el mercado, al menos una hora a la semana. De estos:

6 Para más detalles ver: Plan Nacional para la Prevención y Erradicación del Trabajo Infantil y Adolescente en Chile. SENAME (2006), Chile.

7 Los productos de este esfuerzo fueron: a) La Encuesta Nacional de Trabajo Infantil para lograr su dimensión a nivel nacional. b) El Sistema de Registro Único de las Peores Formas de Trabajo Infantil, diseñado por SENAME en conjunto con Carabineros, Investigaciones y Dirección del Trabajo. c) El estudio cualitativo de las características y necesidades de niños/as y adolescentes involucrados en peores formas de trabajo infantil desarrollado por la Universidad de ARCIS.
- $\quad 107.676$ trabajan en condiciones inaceptables, es decir no asisten a la escuela, trabajan en la calle y/o en jornadas extensas o nocturnas.

- $\quad 88.428$ niños, niñas y adolescentes de 12 a 17 años realizan actividades laborales bajo condiciones aceptables.

- $\quad 42.000$ realizan trabajo doméstico para su casa por más de media jornada (21 horas y más a la semana) $)^{8}$.

El Diagnóstico Nacional citado establece que la mayor parte de quienes trabajan en actividades inaceptables son hombres, y que la tasa de trabajo inaceptable es mayor entre los adolescentes que entre los niños. No obstante lo anterior, estudios como el de la Universidad ARCIS han identificado una presencia mayoritaria de niñas y adolescentes mujeres que varones afectados por Explotación Sexual Comercial Infantil (ESCI).

El Sistema de Registro Único de las Peores Formas de Trabajo Infantil señala que, entre los meses de junio del 2003 y marzo del 2004, se consignaron 388 casos de niños, niñas y adolescentes (NNA) en situación de PFTI (Peores Formas de Trabajo Infantil). De ellos, la mayor concentración se encuentra en el tramo de 17 y 18 años con el 46.6\% y en segundo lugar el tramo de 15 y 16 años con el 28.9\%. Del total, el 27.8\% corresponde a mujeres y el $72.2 \%$ a hombres. La mayor concentración según la situación a la que están expuestos se da en la utilización de menores en prostitución y el trabajo en que se utiliza maquinarias y herramientas que

8 De manera general, se ha establecido que el gobierno prioriza la erradicación del trabajo infantil en sus peores formas, éste es considerado inaceptable para: Todos los niños menores de 12 años que trabajan.; los niños entre 12 y 14 años que laboran catorce horas o más a la semana y/o no estudian; Los adolescentes, entre 15 y 17 años, que trabajan 21 horas o más a la semana y no asisten a la escuela. También, a los que superan las horas establecidas en la jornada completa legal; $A$ todos los niños y adolescentes que trabajan en la calle o de noche. 
requieren capacitación y experiencia, con $12.9 \%$ y 12.4\%, respectivamente (SENAME, 2006)

La particularidad que entrega este último dato es que del 12,9\% -de utilización de niños y niñas para prostitución por adultos-, el 58\% es de niñas y el $48 \%$ de niños. De las cinco regiones donde funciona el sistema (IX, VIII, II, V y Región Metropolitana) la que registra mayor cantidad de casos es la Región Metropolitana con $40.5 \%$ y la VIII Región con 25.8\%. Respecto de la permanencia en el sistema escolar, se señala que el $47.7 \%$ no asiste a la escuela. (SENAME, 2006)

Es importante indicar que progresivamente en Chile el énfasis puesto en la erradicación del trabajo infantil ha ido transitando hacia un énfasis en la disminución de las peores formas de trabajo infantil, e incluso de aquellas que son "indiscutiblemente" peores formas, concepto acuñado por la OIT.

\section{Sobre las Peores Formas de Trabajo Infantil en Chile}

El Trabajo Infantil es considerado una problemática social de preocupación pública, debido a la amplia gama de consecuencias negativas que acarrea. Los efectos que este fenómeno social ocasiona se relacionan con aspectos físicos, psicológicos, sobre la escolaridad, la pobreza y la integración social, todos ellos planteados por Flores (2000) y que naturalmente de modo individual y en su conjunto, constituyen efectos que vulneran los derechos de los niños/as y adolescentes.

El estudio de las consecuencias del trabajo infantil exige realizar una distinción entre aquellos efectos derivados de la exposición de los niños/as y adolescentes al trabajo concebido de manera general y las consecuencias de exponerse a la explotación y comercio sexual.

Cuando se abordan la ESCI, la primera consecuencia es la dramática vulneración de derechos de que son objeto los niños y niñas que lo ejercen. Esto se manifiesta en múltiples dimensiones identificadas en el estudio de la Universidad ARCIS, en documentos de OIT/IPEC y ECPAT:

- Peligro de la violencia física que pueden ejercer sobre él todas aquellas personas que lo explotan, incluyendo a proxenetas, traficantes y clientes ${ }^{9}$.

- Vulnerabilidad frente a las enfermedades de transmisión sexual. Los NNA explotados generalmente no están en posición de negociar prácticas sexuales más seguras; tampoco, por su especial situación, pueden acceder a algún tipo de educación sexual que les ayude a prevenir contagios” ${ }^{10}$.

- Los efectos psicológicos de la explotación sexual son difíciles de evaluar, pero no por ello son menos perjudiciales para los niños/ as. Muchas víctimas presentan sentimientos de vergüenza, culpa y una baja autoestima. Muchos niños/as creen que no son dignos de ser ayudados. Otros niegan la realidad y se auto convencen de que eligieron libremente la prostitución para ayudar a sus familias, o que su proxeneta es realmente un amigo que les da afecto y protección.

- Estigmatización social, pesadillas, insomnio, desesperanza y depresión son comunes, de forma análoga a los sentimientos que presentan aquellas personas que han sido víctimas de la tortura. Para intentar hacer frente a estos sentimientos, muchos menores intentan suicidarse o se vuelven drogodependientes.

9 Según ECPAT existen numerosos y escalofriantes testimonios de niños/as que han sido golpeados, torturados, dejados inconscientes, quemados con cigarrillos, o violados por negarse a trabajar. http://www.ecpat-esp. org/esci/consecuencias.htm

10 http://www.ecpat-esp.org/esci/consecuencias.htm

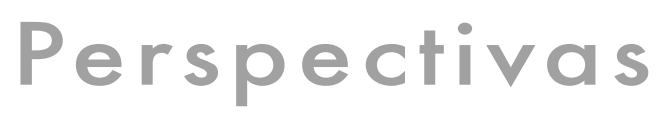




\section{Programas específicos derivados de la política}

Los Programas Sociales destinados a reducir el Trabajo Infantil comparten un sustrato definido por las orientaciones técnicas de la política social. Se exponen, a continuación, los componentes centrales, indicados por la política. En primer lugar, aquellos destinados a combatir el Trabajo infantil en sus peores formas y, luego, ESCI (SENAME, 2006).

\section{A) peores formas de trabajo infantil}

El objetivo general de la política social destinada a enfrentar las PFTI, corresponde a: "Contribuir a promover los derechos del niño, niña y adolescente trabajador y prevenir sus derechos vulnerados por la explotación, mediante procesos de interrupción y reparación, y el fortalecimiento de los recursos personales y grupales, del ámbito familiar y sociocomunitario.

De este objetivo se desprenden los siguientes objetivos específicos:

- Promover los derechos y potenciar los recursos personales y grupales en niños, niñas y adolescentes trabajadores.

- Movilizar los recursos socio-comunitarios y de la red intersectorial tendiente a mejorar las condiciones de bienestar y la promoción de los derechos del niño, niña y adolescente trabajador.

- Interrumpir la situación de explotación laboral y lograr el compromiso y fortalecimiento de la familia o vínculo significativo como recurso protector del niño, niña y adolescente trabajador.

- Contribuir a la resignificación de las experiencias traumáticas vividas y facilitar procesos de reparación en el niño, niña y adolescente trabajador

\section{Componentes centrales de la intervención}

Los enfoques que propone la política para intervenir en la reducción del trabajo infantil son básicamente dos:

- Enfoque promocional reparatorio: con un énfasis en la resignificación de las experiencias vividas.

- Enfoque de trabajo grupal: donde el grupo se constituye en un referente fundamental para la vida de calle y para hacer frente a condiciones de trabajo deplorable, se considera importante relevarlo para facilitar procesos reparatorios.

\section{B) Explotación sexual comercial infantil}

Respecto a la explotación sexual comercial infantil, la política plantea como objetivo general: “Apoyar procesos de reparación de la grave vulneración de derechos de niños, niñas y adolescentes víctimas de explotación sexual comercial y sus procesos de integración familiar y social a través de la ejecución de programas de intervención integrales, de modalidad interdisciplinaria”.

Mientras que los objetivos específicos corresponden a:

- Interrumpir las prácticas de explotación sexual comercial infantil y adolescente, mediante la activación de mecanismos judiciales, orientados a resolver la situación legal del niño/a o adolescente, controlar jurídicamente su situación y facilitar el acceso a la red de Justicia.

- Contribuir a la reparación del daño presente en el niño, niña y adolescente, desde el ámbito psicológico, social y legal apoyando la elaboración de la/s experiencia/s traumática/s.

- $\quad$ Fortalecer recursos protectores, psicológicos y sociales, de las familias y/o adultos significativos. 
- Establecer y facilitar el acceso a redes institucionales y socio-comunitarias, desarrollando estrategias de coordinación pertinentes y permanentes para favorecer los procesos de reparación e integración social de niños, niñas y adolescentes explotados/as.

- Asegurar la inserción social de niños, niñas y adolescentes, incluyendo su inserción en la educación formal, la inserción ocupacional en los casos que se requiera y la atención de salud.

\section{Componentes centrales de la intervención}

Los enfoques que propone la política para intervenir en la reducción de ESCI son:

- Enfoque Integral: considerar a las víctimas de ESCI en la totalidad de su persona, respetando su condición de sujetos que requieren contar con una protección especial.

- $\quad$ Enfoque Multidisciplinario: debido a la multicausalidad del problema.

- $\quad$ Enfoque de Reparación e Integración Social: ya que los daños que experimentan las víctimas de explotación sexual comercial alcanzan distintas esferas de su comportamiento, a nivel afectivo, a nivel cognitivo, a nivel corporal e interpersonal y ha implicado la vulneración de distintos derechos. Se buscará la interrupción de la violencia en la que se encuentra el niño, niña o adolescente y la resignificación de la(s) experiencia(s) de manera de superar los atropellos a sus derechos vividos como explotaciones.

En general, la política chilena de reducción del trabajo infantil en sus peores formas apunta básicamente a su interrupción o reducción en la medida que condiciona la estabilidad escolar y, en los casos de explotación sexual comercial infantil, incuestionablemente peores formas, apunta a su interrupción total, ya que lo define como una de las formas de trabajo infantil más vulneradoras de los derechos de los niños/as.

\section{ARGENTINA}

La presencia pública en medios de prensa e investigaciones difundidas.

En la ciudad de Córdoba, el trabajo infantil fue tema central en la Sección Sociedad de su principal diario, el día 16 de agosto del 2005 por última vez. La nota se basa en datos del libro Infancia: varios mundos. Acerca de la Inequidad en la infancia argentina ${ }^{11}$ y trata sobre las diversas problemáticas que afectan a la infancia argentina y que son abordadas en el libro: habitat, alimentación, juego, educación, trabajo, desamparo.

La nota periodística rescata del capítulo del libro dedicado a este tema ${ }^{12}$ datos cuantitativos producidos por la CONAETI (Comisión Nacional de Erradicación del Trabajo Infantil), por un lado, $\mathrm{y}$, por otro, conceptos tales como el ocultamiento "que entre otras cosas impide saber a ciencia cierta cuántos niños aportan dinero al hogar”; los de "vulnerabilidad, precariedad y clandestinidad" como lo que caracteriza las condiciones laborales de los niños/as” y la explicación del problema en el marco de la desigualdad social imperante en tanto "el trabajo infantil no es un fenómeno coyuntural. La prolongada exclusión de los ámbitos laborales que sufren los adultos va generando cada vez más exclusión social”.

En el texto y capítulo mencionado, las autoras realizan un recorrido histórico de la bibliografía y legislación existente en Argentina sobre el tema trabajo infanto juvenil, lo que les permite reconstruir concepciones que subyacen en las visiones y

11 Dirigido por Alicia Entel y publicado por la Fundación Walter Benjamín, UNICEF y la Fundación Arcor en julio del 2005

12 Escrito por Mariela Macri, Myriam Ford, Carolina Berlimer y María José Molteni. Investigación "Trabajo Infanto-juvenil, su aproximación conceptual y sociocultural". 
acciones sobre el tema. Se marcan cuatro momentos: el trabajo infantil-adolescente en el marco de la cuestión social, las políticas de mediados del siglo $\mathrm{XX}$; la situación en la última dictadura y finalmente desde el retorno a la democracia.

Respecto al último momento, señalan la convivencia en los años 90 de "dos posiciones de naturaleza teórica e ideológica diferente que han contribuido a colocar el tema del trabajo infanto-adolescente en un lugar relevante de la agenda política para la infancia: "la "posición abolicionista” y la posición "protección/defensa”, que las mismas autoras se ocupan de definir"13.

Las autoras no toman postura explícita sobre estas posiciones teóricas, pero en sus reflexiones finales señalan algunas de las características predominantes de la realidad del trabajo infantil, asociando las condiciones laborales de los niños/as a los conceptos de "vulnerabilidad, precariedad, y clandestinidad”. También resaltan como un problema la naturalización del mismo, en el imaginario cultural de las familias y el encubrimiento que significa "la calle” como ámbito laboral de los niños/as, haciendo invisible la magnitud de su aporte económico a la economía familiar. Finalmente, otro elemento central que marcan es su explicación en el marco de

13 Explican que la concepción abolicionista reserva el término trabajo infantil para los niños/as hasta los 12 años y considera que "cualquier trabajo infantil es fuente de peligro y la única manera de evitar el riesgo consiste en eliminarlo; con lo cual la meta última de toda acción debería ser la abolición del trabajo infantil (....). Según esta postura la universalización de la educación básica es el único instrumento que asegura (....) igualdad, en un doble sentido. Como requisito mínimo -aunque obviamente no garantía- de posible ingreso al mercado de trabajo, y como "lugar" más idóneo de construcción de la bases de la ciudadanía de la infancia" (cita a García Méndez y Aradsen, 1997:43. Definen a la posición "protección/ defensa" como aquella que entiende al trabajo infantil como "cualquier actividad de un menor de edad que (....) contribuye a la satisfacción de las necesidades materiales básicas, estas últimas relacionadas con el desarrollo físico-biológico y con los indispensables procesos de socialización, en un contexto no sólo individual sino familiar". Según esta postura, el trabajo bajo una apropiada protección y supervisión es un vehículo esencial de socialización, formación y autoestima y la participación económica de los niños sería beneficiosa en la medida en que sea compatible con un desarrollo saludable. la exclusión de los adultos de los ámbitos laborales, la desigual distribución de ingresos, de la riqueza, la salud y la educación y la inexistencia de una política de Estado que garantice una distribución más equitativa.

Ante esta caracterización del problema, las líneas de acción propuestas expresan la postura de la "erradicación”, al hablar de la necesidad de "una política de estado que embista contra este funcionamiento cínico del fenómeno, lo desenmascare y lo desnaturalice" y la necesidad impostergable de "repensar el fortalecimiento de la posición de los adultos”.

Ante esta forma de presentar el tema, surge una serie de interrogantes tales como: cuando se hace referencia a una "política de estado que embista contra el funcionamiento cínico del sistema”, se refiere a: ¿atacar la exclusión de los adultos de los ámbitos laborales y la desigual distribución del ingreso?; o a ¿desnaturalizar en las familias de los sectores pobres el sentido desde el cual los niños/as son reconocidos como trabajadores?, o a ¿reconocer que la calle en ciertas condiciones se transforma en un ámbito peligroso para los niños/as?, ¿las familias no reconocen o no toman precauciones frente a situaciones de peligro en las que pueden verse sometidos sus hijos?, o cuando permiten o promueven que sus hijos trabajan, ¿que significado le asignan al mismo?, etcétera. Y así podríamos seguir presentando diversas interrogantes que indican que es necesario profundizar aún más para explicar y comprender la existencia concreta, real y palpable de la realidad del trabajo infantil.

\section{La política de infancia}

La Argentina es un país participante del Programa Internacional para la Erradicación del Trabajo Infantil OIT/IPEC desde 1996. Conformó la Comisión Nacional para la Erradicación del Trabajo Infantil (CONAETI) en mayo de 1997 y la formalizó en agosto del 2000 por el decreto $\mathrm{N}^{\circ} 719$, en el ámbito del Ministerio de Trabajo, Empleo y Seguridad Social. 
La CONAETI está integrada por instituciones del ámbito estatal (Ministerios de Trabajo, de Educación, de Salud, de Relaciones Exteriores, de Defensa, de Desarrollo Social y Medio Ambiente, de Economía, del Interior, de Justicia, de Culto y Cultura; Dirección Nacional de la Juventud, Instituto Nacional de Estadística, Consejo Federal de Trabajo, Consejo Nacional de Niñez, Adolescencia y Familia) y del ámbito societal (Unión Argentina de Trabajadores Rurales y estibadores; Confederación General del Trabajo, Central de Trabajadores Argentinos, Federación Agraria Argentina, Sociedad Rural Argentina, Unión Industrial Argentina, Conferencia Episcopal Argentina, Caritas- Argentina); y tiene a OIT/IPEC y a Unicef como organismos asesores.

Entre sus principales actividades, se desatacan la recopilación y análisis de la normativa que regula el trabajo infantil en Argentina y de las estadísticas sobre el mismo; además de la realización de convenios y acuerdos institucionales con gobiernos y organizaciones en torno a acciones que prevengan y erradiquen el trabajo infantil, a través de dos estrategias complementarias: la inclusión en el sistema educativo de los niños/as y el fortalecimiento económico-laboral de las familias.

Los informes realizados por la CONAETI expresan logros en sus objetivos y estrategias, a modo de experiencias puntuales y de una ampliación de actores participantes en la misma. Pero se está muy lejos de poder hablar de una política clara en sus definiciones y en sus acciones, con relación al tema del trabajo infantil. Esta misma realidad se expresa en las dificultades para construir un registro estadístico a nivel nacional.

La última medición nacional y primera específica sobre el tema, es la encuesta emprendida por el Ministerio de Trabajo y desarrollada en forma conjunta con el INDEC en el marco del Programa "Encuesta y Observatorio de Trabajo Infantil" denominada "Encuesta de Actividades de Niños, Niñas y Adolescentes” (EANNA) que se acordó entre el Gobierno Argentino y el Programa Inter- nacional para la Erradicación del Trabajo Infantil (IPEC) de la OIT fue realizada en el último cuatrimestre del 2004.

\section{Las políticas para reducir los efectos negativos del trabajo infantil}

Dar cuenta del marco institucional y jurídico de esta a la Secretaría de Protección Integral del Niño y Adolescente, es "recrear" las condiciones, cambios y conflictos, en el marco de la Reforma del Estado, pero también y con un mismo nivel de significación de "disputas" "posicionamientos” y "hegemonías” al interior del partido gobernante y de las relaciones de éste a nivel nacional.

La ley No 9053 -de Protección Judicial del Niño y el Adolescente-, actualmente en vigencia, se puede considerar un avance en relación a la anterior-Ley 4873- en tanto limita la discrecionalidad del juez, estableciendo procedimientos y plazos, pero, en otros sentidos, quedan abiertas instancias para la arbitrariedad. Al no brindarse los canales necesarios para el ejercicio pleno de los derechos que plantea el texto de la ley, debido al colapso judicial y a la inexistente coordinación con los demás ámbitos institucionales encargados de la problemática, se puede decir que estos avances son aparentes.

Pretendiendo identificar acciones vinculadas a la realidad de niños/as trabajadores se realizó un recorrido sobre la información disponible en la página oficial del gobierno de la provincia de Córdoba en Internet. Al inicio de la misma, en su presentación, la Secretaría expresa: "El Gobierno de la Provincia de Córdoba a través de su órgano Legislativo creó la Secretaría de Protección Integral del Niño y el Adolescente regida bajo la Ley $\mathrm{N}^{\circ}$ 9060/02 y modificada por la ley No 9117/03, la cual regula las funciones de la Secretaría y permite, por primera vez, llevar a cabo la ejecución efectiva de políticas de Estado vinculadas a la asistencia, prevención y promoción de los derechos de Niños y Adolescentes afines con los conceptos establecidos por la Convención de los Derechos del niño, introducidos

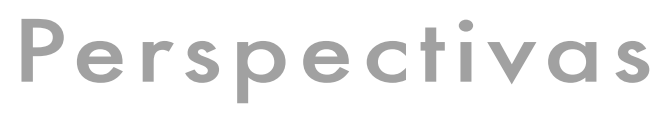


en la Constitución Provincial en la última reforma. Desde la Secretaría de Protección Integral del Niño y el Adolescente, se llevó a cabo una vasta reingeniería en programas y planes sociales tendientes a fomentar la cultura del trabajo como base y fundamento de toda sociedad organizada" ${ }^{14}$.

Dentro de los programas cuyos destinatarios son niños/as y adolescentes judicializados, se menciona al Programa Protección Joven (ex Policía Juvenil del CPPM) que, además de cumplimentar medidas tutelares como constataciones, retiro de hogar, internaciones, contempla la posibilidad que los propios niños y adolescentes, puedan solicitar amparo. No obstante, el objetivo de este programa refiere exclusivamente a la población de niños/as y adolescentes en situación de calle. Así lo expresa: "Tiene como objetivo acompañar a los niños y jóvenes en situación de calle, tratando de modificar hábitos, costumbres, modalidades, brindándoles otras oportunidades desde distintos Programas de esta Secretaría, como así también, contener a las familias de los mismos, posibilitándoles la escolarización en la educación formal y la capacitación productiva”.

Dentro de los Programas Generales, menciona el Programa “Abriendo Puertas" que, si bien no explicita objetivos ni actividades del mismo, se trata de una reedición de los Programas de Capacitación Laboral, que, desde los años 90, se venía implementando en la Provincia de Córdoba: Talleres de Capacitación Laboral “Eva Perón” y Programa Crecer, los que fueron cerrados con el cambio de gobierno en la provincia, en el año 2000. Con la salvedad que el Programa Abriendo Puertas, con financiamiento nacional, se focaliza en una población de 500 beneficiarios para la capacitación de oficios laborales.

14 El subrayado es nuestro, en tanto nos interesa remarcar que si bien se habla de la "vasta reingeniería en programas y planes sociales....", y la "ejecución efectiva de políticas de Estado vinculadas a la asistencia, prevención y promoción...." Los programas citados en la página son una reedición de los "viejos programas del CPPM", con nuevos ropajes, considerando la caracterización ya explicitada con respecto a las políticas de infancia en la provincia de Córdoba.
Si bien la población beneficiaria son adolescentes entre 15 y 19 años, interesa "visibilizar" la perspectiva de la selección de esta población a ser incluida en las actividades de capacitación ${ }^{17}$ : Esta es definida como de "sectores carecientes”; “en situación de trabajo callejero o excluidos de las posibilidades de desarrollo positivo, tienen en la ciudad de Córdoba un espacio para construir esperanza y quitarse algún día el yugo del infortunio”.

Los funcionarios responsables describen de la siguiente forma a los usuarios de los programas: "En general, los jóvenes provienen de familias desorganizadas, muchos tienen antecedentes de consumo de sustancias tóxicas, hay varios padres y madres precoces y prácticamente todos tienen experiencia en trabajos callejeros o deambulan desde edades tempranas. Hay casos también de alumnos involucrados en conflictos penales y muy pocos demuestran tener normativas de convivencia social incorporadas".

En los distintos Programas de la Secretaría de Protección Integral del Niño y Adolescente no se explicita la temática del trabajo infantil como problemática que requiere del desarrollo de programas asistenciales, promocionales y preventivos, como se desprende de las funciones de dichas Secretaría. No obstante, hay que llamar la atención sobre los discursos dominantes ("niños en situación de calle”; “con procedencia de familias desorganizadas”, "niños en situación de riesgos”, etc.;) donde las respuestas estatales siguen "atadas a las trampas de la asistencia/judicialización” a base de concepciones negativas de la infancia pobre que se basa en la tríada riesgo-incapacidad-peligrosidad.

\section{Ley Nacional No 26061 de Protección Integral de Derechos del Niño y del Adolescente}

Recientemente aprobada -septiembre de 2005-y reglamentada en el mes de Abril del corriente

15 Informe de Investigación: Adolescentes "en riesgo social" y su relación con las políticas sociales 
año, constituye un cambio legislativo central que aborda la problemática social de la Infancia desde una perspectiva de derechos. Los cambios centrales se verifican en la definición del niño/a y adolescente como sujeto de derecho, participando activamente en todos los problemas que lo involucran, estableciendo responsabilidades familiares, comunitarias y sociales para garantizar el pleno ejercicio de los derechos y definiendo como principal garante al Estado. Define que es éste quien deberá formular las Políticas Sociales Integrales para asegurar el pleno ejercicio de los Derechos establecidos.

La Ley 26061 incorpora la temática del trabajo como Derecho, en su artículo 25: "Los Organismos del Estado deben garantizar el derecho de las personas adolescentes a la educación y reconocer su derecho a trabajar, con las restricciones que impone la legislación vigente y los convenios internacionales sobre erradicación del trabajo infantil, debiendo ejercer la inspección del trabajo contra la explotación laboral de las niñas, niños y adolescentes”. Explicita que “este derecho podrá limitarse solamente cuando la actividad laboral importe riesgo, peligro para el desarrollo, la salud física, mental o emocional de los adolescentes y que los Organismos del Estado, la sociedad y en particular las organizaciones sindicales coordinarán sus esfuerzos para erradicar el trabajo infantil y limitar toda forma de trabajo legalmente autorizada cuando impidan o afecten su proceso evolutivo.”16

Tal como se enuncia en el presente artículo, se observa que el Derecho al Trabajo se garantiza

16 La información que se consigna es la que se obtiene de la difusión del programa en diarios locales (La voz del interior, 23/06/02: Sección Oasis: Un lugar donde se abren puertas para salir de los riesgos de la calle), en página Internet (versión html del archivo: http://web2.cba. gov.ar/web/News.nsf) Área Agencia Córdoba Solidaria, 27/12/02, "400 chicos en situación de calle recibieron los certificados del Programa Abriendo Puertas. Y en Dirección de Prensa: Gacetilla de Prensa, 05/09/03: "El presidente del Comité para la defensa de la salud, la ética y los derechos humanos visitó el Programa "Abriendo Puertas". sólo para los adolescentes, reconociendo todas las limitaciones que imponen los Convenios Internacionales vigentes, explicitándose en la reglamentación del mencionado artículo: "las prescripciones contenidas en el artículo que se reglamenta deben interpretarse como complementarias de las contenidas en la Ley de Contrato de Trabajo No 20.744 y sus modificaciones, como así también con las que integran los Convenios 138 y 182 de la Organización Internacional del Trabajo (OIT).”17

Realizando una revisión completa sobre la Ley 26061, se observa que, en su artículo 9a Derecho a la Dignidad e Integridad Personal, reitera la obligatoriedad de protección contra cualquier forma de explotación económica, que puede ser interpretada como las peores formas de trabajo infantil que surgen de los Convenios 138 y 182 de OIT.

Con relación al Derecho a la Salud, menciona en el artículo 14 algunas cuestiones generales en las que se garantiza el acceso a Programas de Prevención y Protección de la Salud, sin especificar sobre atención de los/as adolescentes trabajadores.

En cuanto al Derecho a la Educación, en uno de sus párrafos el Artículo 15 señala "Por ninguna causa se podrá restringir el acceso a la educación debiendo entregar la certificación o diploma correspondiente", cuya reglamentación explicita Artículo 15: "Los organismos estatales promoverán acciones para suscitar la reinserción escolar de los niños, niñas y adolescentes que por distintas causas hayan dejado de concurrir a la escuela”, observando que, si bien se reconoce el derecho al trabajo de los adolescentes, no aparece en forma explícita en la legislación, una vinculación entre este derecho y los derechos de promoción y protección de su salud, como así también alguna forma específica que permita el ejercicio del derecho a la educación, respetando su condición de trabajador.

Se observa que la Ley 26.061 sí incorpora en su artículo 17 la Prohibición de Discriminar por estado

17 Ley 26.061. 
de Embarazo, Maternidad y Paternidad, obligatoriedad de las instituciones públicas y educativas de garantizar las condiciones necesarias para que las jóvenes embarazadas puedan finalizar sus estudios. También establece en su artículo 18: Protección de Maternidad y Paternidad, medidas tendientes a garantizar las condiciones adecuadas para el transcurso del embarazo, parto y lactancia.

Los artículos precedentes nos permiten decir que, si bien existe un reconocimiento del Derecho al Trabajo del Adolescente, el cuerpo legal no incorpora el Derecho a la Salud, como así también al Derecho a la Educación.

Con relación al Derecho de Libre Asociación, se reconoce la posibilidad de iniciar un proceso tendiente a la conformación de organizaciones representativas de aquellos grupos de adolescentes trabajadores que puedan reclamar las adecuaciones de las instituciones públicas educativas y sanitarias, en función de alcanzar los objetivos propuestos por la presente ley. En el artículo 23, referido al Derecho a la libre asociación, se reconoce que "las niñas, niños y adolescentes tienen derecho de asociarse libremente con otras personas, con fines sociales, culturales, deportivos, recreativos, religiosos, políticos, laborales o de cualquier otra índole, siempre que sean de carácter lícito y de conformidad a la legislación vigente”.

Pasando a analizar las Medidas de Protección Integral, el artículo 35, referido a la aplicación de las medidas, dice: "Se aplicarán prioritariamente aquellas medidas de protección de derechos que tengan por finalidad la preservación y el fortalecimiento de los vínculos familiares con relación a las niñas, niños y adolescentes. Cuando la amenaza o violación de derechos sea consecuencia de necesidades básicas insatisfechas, carencias o dificultades materiales, económicas, laborales o de vivienda, las medidas de protección son los programas dirigidos a brindar ayuda y apoyo incluso económico, con miras al mantenimiento y fortalecimiento de los vínculos familiares”.

El apoyo y fortalecimiento del grupo familiar aparecen en la Ley 26.061 como eje central en la mayoría de las Medidas de Protección ante situaciones de vulneración de derechos, proponiendo, en su artículo Artículo 37, una serie de Medidas de protección: "Comprobada la amenaza o violación de derechos, deben adoptarse, entre otras, las siguientes medidas:

a) Aquellas tendientes a que las niñas, niños o adolescentes permanezcan conviviendo con su grupo familiar;

b) Solicitud de becas de estudio o para jardines maternales o de infantes, e inclusión y permanencia en programas de apoyo escolar;

c) Asistencia integral a la embarazada;

d) Inclusión de la niña, niño, adolescente y la familia en programas destinados al fortalecimiento y apoyo familiar;

Cuidado de la niña, niño y adolescente en su propio hogar, orientando y apoyando a los padres, representantes

e) legales o responsables en el cumplimiento de sus obligaciones, juntamente con el seguimiento temporal de la familia y de la niña, niño o adolescente a través de un programa;

f) Tratamiento médico, psicológico o psiquiátrico de la niña, niño o adolescente o de alguno de sus padres, responsables legales o representantes;

g) Asistencia económica.

La presente enunciación no es taxativa”. 
Por lo expuesto, se observa que la Ley 26.061 representa un avance histórico en lo relativo a la superación de la lógica del Paradigma de la Situación Irregular, plasmado en la derogada Ley 10903 de Patronato, estableciendo las condiciones legales para el respeto y promoción de los Derechos de los niños/as y adolescentes, delegando la responsabilidad de garantizarlos al Estado y comprometiendo, asimismo, a todos los actores sociales en el Principio de Corresponsabilidad.

Con relación al tema del Trabajo Infantil, especialmente de la franja de 5 a 13 años, no existe reconocimiento del mismo como derecho. Por el contrario, se hace referencia a él como una actividad que podría interpretarse como vulneración de otros derechos reconocidos. Asimismo, el reconocimiento al Derecho del Trabajo del Adolescente aparece con las limitaciones de los Convenios legales nacionales e internacionales, sin observar que exista adecuación de sistemas educativos o de salud, para compatibilizar el ejercicio integral de los mismos.

A pesar de estos avances, queda pendiente la adecuación de la legislación provincial a lo que establece la ley nacional 26.061, cuestión que se encuentra en proceso de elaboración y que será de vital importancia a la hora de diseñar las Políticas Sociales dirigidas a todos/as los niños/as, como así también de abordar los dos problemas centrales: la desjudicialización y desinstitucionalización. Esta tarea aún pendiente interpela no sólo a las instituciones públicas, sino a la sociedad en su conjunto. La Ley Nacional abre un abanico de posibilidades para avanzar en la exigibilidad de los derechos sociales, en el reconocimiento de la participación protagónica de niños/as y adolescentes en estos procesos y en el reclamo por políticas sociales integrales y universales.

\section{Análisis de los discursos y sus contextos}

Tanto en Chile como en Argentina, se evidencia un cambio sustantivo en la lógica de los enfoques que sostienen la política de infancia y, dentro de ella, las orientaciones de los programas para enfrentar el Trabajo Infantil. Sin embargo, el tránsito de este proceso no ha estado libre de los resabios del enfoque de la irregularidad social.

En el caso Argentino, los actores políticos del Ministerio de la Solidaridad dan cuenta de que algunos de los programas se identificaban con la anterior gestión, "eran programas excesivamente costosos" y que, como en el caso del Programa Crecer, el Equipo Técnico era visualizado con "poder de movilización de estos sectores poblacionales”. De allí que haya sido necesario cambiar los programas dentro de la nueva lógica instalada por la actual administración, a través de la expansión de las transformaciones ocurridas a nivel estatal, iniciadas por la administración del Dr. Angeloz y desarrolladas por la administración de Mestre. La nueva administración justicialista creó, en Marzo de 2000, el Programa Sol, que atiende dos áreas: becas de estudio, a nivel secundario y universitario, y se "terciarizó" el área de capacitación laboral, con un cupo para 500 jóvenes. Quedando excluido un sector importante de la población beneficiaria, tanto en relación con la capacitación como con la cobertura de las becas escolares, donde no sólo se excluye en relación al número, sino que en cuanto al tipo de beneficiario, no se incluye el nivel primario, y se agrega el nivel universitario y también como criterio de elegibilidad, se tuvo en cuenta los promedios obtenidos en la escuela.

Durante el año 2000, se presentaron proyectos a organismos internacionales, para recibir asistencia técnica y financiera, en el marco de programas sociales provinciales” (Informe op. Cit. Año: 2000).

En la lógica de los funcionarios responsables, se construyen aún discursos acerca de esta población, caracterizándola desde la "peligrosidad", esto es, los procesos de victimización/criminalización. También se percibe "el contrato de obediencia-reciprocidad moral” esperado por los beneficiarios, en palabras del Presidente de la Agencia Córdoba Solidaria, en oportunidad de la entrega de Certifi-

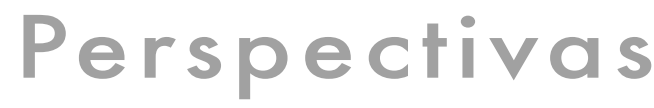


cados: "Hemos dado recién el primer paso -continuó el Titular de la Agencia Solidaria- Ustedes cumplieron con su parte de no permanecer en la calle, de asistir a las clases y tratar de aprender todo lo que podían en esta primera etapa. Nosotros hemos tratado de cumplir con el nuestro y el lunes, a partir de las 9 de la mañana, cobrarán por adelantado el mes de diciembre. En primer lugar, quiero aclarar que según se nos informó desde el Consejo Nacional del Menor, estos proyectos se pagan a mes vencido y ante una gestión realizada por funcionarios de esta Agencia, conseguimos los fondos para que se pudiera pagar por adelantado y les pido que renovemos el compromiso de mantenernos lejos de las calles y de sus vicios, y nosotros nos comprometemos para que a ustedes nos les falten los recursos durante el mes de enero. En febrero retomaremos las actividades, con la beca y la capacitación”.

En el caso Chileno, también se evidencia un tránsito árido desde una lógica represiva-protectiva a una lógica de derechos. En Chile, es usualmente proclamada la necesidad de entender y considerar los mecanismos culturales a través de los cuales las ideas globales son recibidas y adaptadas a los contextos locales (Pilotti, 2000: 4), especialmente cuando en el país se suscriben pactos internacionales. Estos mecanismos deben considerar cualitativos cambios en las percepciones legales y sociales sobre infancia. Los cambios en este punto no pueden fallar en considerar los valores, sensibilidades, puntos de resistencia que se generan en la sociedad frente a nuevas conceptualizaciones sobre la infancia.

El discurso de la política de infancia instaurada en Chile en los últimos años, si bien se enmarca en los principios centrales de la perspectiva de derecho, no logra plasmar en el diseño específico de sus programas las características propias de los contextos donde cada fenómeno se desarrolla. En el caso del Trabajo Infantil, los programas tienden a buscar la interrupción de la actividad como resultado central, sin poner especial atención al significado que el trabajo tiene para el niño/o y su familia, esto explica que los programas tampoco incorporen en sus componentes una alternativa de reconversión laboral para las familias afectadas por este fenómeno, sugiriéndose que, en la explicación oficial del fenómeno, el trabajo infantil podría ser una opción de las familias, por sobre una única alternativa para la sobrevivencia.

En el caso de los Programas derivados de la Política para erradicar la Explotación Sexual Comercial Infantil (ESCI), el discurso oficial no establece relaciones vinculantes entre este fenómeno y el impacto del neoliberalismo que irrumpe a través de los medios, elevando el consumo como fin último y la industria del sexo como canal para alcanzar tal finalidad. De este modo, se focaliza la comprensión de la problemática como la consecuencia de familias inadecuadas.

En tal sentido, el avance del nuevo paradigma es, escasamente, concientizar la situación de víctima de los niños/as afectados por ESCI. Esto se evidencia, aún más, cuando, existiendo información sobre los clientes, no existe un programa que contemple intervenciones dirigidas a reducir la acción de los victimarios, tanto los proxenetas como los “clientes". El discurso de la política es ciego a estos actores, desdibujando el rol de la política social en este ámbito.

\section{De la política a los programas sociales de intervención directa}

El diseño y ejecución de programas sociales que aborden específicamente la problemática del trabajo infantil se encuentra en etapas de desarrollo diferente en cada país, ya que en Argentina existen algunas iniciativas emergentes que tratan de configurar respuestas frente a este fenómeno, pero que no parecen enmarcarse en propuestas oficiales que asignen presupuesto específico y exclusivo para enfrentarlo. En el caso chileno, se han desarrollado orientaciones técnicas específicas para el diseño de programas que reduzcan el trabajo infantil, y aquellas expresiones de sus peores formas. Debido a esta diferencia, el análisis en cada país se desarrollará 
en niveles de especificidad diferenciados, ya que la existencia de programas que atienden exclusivamente la problemática del Trabajo Infantil permite un análisis más detallado de los componentes de los programas $y$, ante la inexistencia de este tipo de programas o su carácter emergente, el tipo de análisis se realiza desde una perspectiva más macro, más próxima al análisis de política pública.

\section{Chile}

La política para abordar el Trabajo Infantil en Chile establece áreas centrales de intervención dirigidas a niños, niñas y a adolescentes, así como a las familias, las comunidades y las instituciones. Para estudiar cómo estos componentes se implementan en la realidad a través de programas sociales en Instituciones colaboradoras del Servicio Nacional de Menores, se describen a continuación programas que organismos internacionales como UNICEF y OIT identifican como buenas prácticas en Santiago de Chile. De este modo, se explorará cómo estos programas se articulan y/o tensionan con los contextos descritos en capítulos anteriores de esta investigación.

Para el análisis, se separaron aquellos programas diseñados para abordar el Trabajo infantil de aquellos específicamente establecidos para reducir la Explotación Sexual Comercial Infantil.

Programas de reducción del Trabajo Infantil

\begin{tabular}{|c|c|c|}
\hline $\begin{array}{l}\text { AREAS DE } \\
\text { INTERVENCIÓN }\end{array}$ & $\begin{array}{c}\text { PROGRAMA DE NIÑOS Y NIÑAS EN } \\
\text { SITUACIÓN DE CALLE, HOGAR DE } \\
\text { CRISTO }\end{array}$ & PROGRAMA PRONIÑO, CODENI \\
\hline SALUD & $\begin{array}{l}\text { Derivaciones a servicios médicos detectados } \\
\text { como necesarios }\end{array}$ & $\begin{array}{l}\text { Derivaciones a servicios médicos detectados } \\
\text { como necesarios }\end{array}$ \\
\hline FAMILIA & $\begin{array}{l}\text { Eje de la intervención, se trata de modificar } \\
\text { las conductas al interior de las familias, } \\
\text { especialmente con las madres, para así } \\
\text { transformar el contexto de los NNA, } \\
\text { convirtiéndolo en uno más afectivo, menos } \\
\text { violento y que resignifica el valor de la } \\
\text { educación, vs. El del trabajo infantil. }\end{array}$ & $\begin{array}{l}\text { Es uno de los componentes del programa, } \\
\text { pero se ofrece selectivamente, ya que } \\
\text { no todas las familias tienen acceso a } \\
\text { participar en talleres de madres o padres. } \\
\text { La participación de una familia en éstos } \\
\text { está mediada por el diagnóstico de la } \\
\text { dupla psico-social del Centro donde se } \\
\text { implemente este programa. }\end{array}$ \\
\hline EDUCACION & $\begin{array}{l}\text { Componente central de intervención, con el } \\
\text { objeto de asegurar permanencia y disminuir } \\
\text { factores expulsores al interior del sistema } \\
\text { escolar. Se han gestionado fondos para } \\
\text { re-escolarización, que ha beneficiado a } \\
\text { los NNA de este programa, para apoyar } \\
\text { su rendimiento escolar, partiendo con } \\
\text { competencias básicas pre-escolares. Se } \\
\text { observan habilidades matemáticas en estos } \\
\text { grupos. } \\
\text { El objetivo central en este componente es la } \\
\text { retención escolar y asegurar la conciencia } \\
\text { de la educación como un derecho, } \\
\text { sensibilizando tanto a los participantes } \\
\text { del programa como a las comunidades } \\
\text { escolares. }\end{array}$ & $\begin{array}{l}\text { Componente central de intervención, con el } \\
\text { objeto de asegurar permanencia y disminuir } \\
\text { factores expulsores al interior del sistema } \\
\text { escolar. } \\
\text { El objetivo central en este componente es la } \\
\text { retención escolar y asegurar la conciencia } \\
\text { de la educación como un derecho, } \\
\text { sensibilizando tanto a los participantes } \\
\text { del programa como a las comunidades } \\
\text { escolares. }\end{array}$ \\
\hline
\end{tabular}




\begin{tabular}{|l|l|l|}
\hline $\begin{array}{l}\text { CAPACITACION } \\
\text { LABORAL }\end{array}$ & $\begin{array}{l}\text { No existe oferta en esta línea. Existen } \\
\text { algunas experiencias aisladas de capaci- } \\
\text { tación en un oficio, con el apoyo de otras } \\
\text { fundaciones. }\end{array}$ & $\begin{array}{l}\text { Se ofrece un número reducido de becas para } \\
\text { algunos participantes del programa que les } \\
\text { financia estudios de educación superior y } \\
\text { ofrece, además, el acompañamiento de un } \\
\text { tutor/ voluntario en este proceso. }\end{array}$ \\
\hline APOYO LEGAL & $\begin{array}{l}\text { Cuando se requiere algún tipo de servicio } \\
\text { de este tipo, se deriva. }\end{array}$ & $\begin{array}{l}\text { Cuando se requiere algún tipo de servicio } \\
\text { de este tipo, se deriva. }\end{array}$ \\
\hline APOYO MATERIAL & $\begin{array}{l}\text { Componente relevante en el área de } \\
\text { equipamiento escolar, se entrega el com- } \\
\text { plemento necesario a las familias, para } \\
\text { que los niños puedan contar con útiles y y } \\
\text { uniforme escolar. }\end{array}$ & $\begin{array}{l}\text { El programa contempla, como componente } \\
\text { estable, la entrega de una beca escolar } \\
\text { para cada uno de los participantes en el } \\
\text { programa que debe destinarse a gastos } \\
\text { escolares: útiles, uniformes, matrículas, } \\
\text { movilización, etc. }\end{array}$ \\
\hline
\end{tabular}

\section{Las innovaciones de los programas}

\section{El eje en la educación}

Ambos programas establecen un eje prioritario consistente en favorecer la retención escolar y la estrategia que se ha privilegiado es la mediación escolar. Se evidencia con esto, que, cuando se aborda el Trabajo Infantil, en sus peores formas, diferenciándolo de aquellas incuestionables peores formas, uno de sus efectos, que se trata de contra-restar más fuertemente, es su impacto en la escolarización de los NNA

\section{Centralidad del contexto versus el NNA como “objeto clínico”}

El programa Niños y Niñas en Situación de Calle del Hogar de Cristo ha realizado un esfuerzo significativo por descentrar la intervención de un carácter terapéutico y concentrarla en el contexto que determina que los NNA del programa sean niños trabajadores. Esto se refiere a:

- Focalizar esfuerzos en procesos de cambio personal y familiar de las madres y/o adultos significativos, modificando patrones de relación violentos, sobre-valoraciones del trabajo infantil, y sub-valoraciones de los procesos de escolarización de sus hijos. Este cambio ha generado no sólo una resignificación de la relación familiar, sino también una dignificación de las madres y/o adultos significativos, al reconocer en ellas mismas historias comunes de explotación y violencia.

- Énfasis en la mediación escolar, como estrategia de transformación del sistema escolar. Se trata de sensibilizar a los actores escolares con la temática del trabajo infantil, empoderar a los sujetos de atención con su derecho a la educación, y generar un ambiente más acogedor para estos NNA en el contexto educacional. Los logros de estos esfuerzos se materializan en que de los 106 NNA involucrados en el programa, el $90 \%$ de sus escuelas fue contactada para realizar la mediación, y 93\% de ellos, permanece en el sistema escolar.

- Incipiente experiencia en el mejoramiento del rendimiento escolar a través del proyecto intersectorial (SENAME - MINEDUC) de re-escolarización, a través del cual se invierte en reforzar con especialistas habilidades cognitivas básicas.

\section{Co-financiamiento de los Programas}

El Programa ProNiño ha innovado sustantivamente la combinación de recursos fiscales y privados en su implementación. Diversos estudios han establecido las bondades de instalar sinergias, "atrayendo fuentes de financiamiento mediante la idea del Consorcio con agentes heterogéneos, organismos 
de la sociedad civil y medios tanto públicos como privados” (Caselet, 2006). La autora considera que la mejor forma de perpetuar los resultados de diversos programas es que los sistemas públicos consideren estas estrategias de financiamiento, lo que contribuye a su vez a generar innovaciones en los contextos institucionales y de políticas para la solución de problemas. En este Programa en particular, la estrategia de financiamiento compartido comprende la utilización de recursos de infraestructura y algunos servicios sociales financiados por el Estado, para la implementación de un programa distinto al estatal, financiado por privados. El financiamiento privado implica fondos directos proporcionados por Movistar y el aporte de voluntarios con donaciones regulares.

\section{Inclusión del Voluntariado}

El Programa ProNiño ha incorporado, en su oferta, el apoyo de voluntarios de la empresa Movistar, quienes entregan parte de su tiempo para el desarrollo de actividades recreativas con los NNA del Programa. La forma de inclusión es interesante, ya que supera la sola entrega de recursos financieros y compromete a los voluntarios en la entrega de tiempo personal para compartir con los niños/as. Se suma a ello, el impacto indirecto de ampliar el mundo social al que cotidianamente estos niños/as tienen acceso. Además, el Programa ha instalado otros ámbitos de apoyo, aparte del recreativo, generando relaciones tipo "mentor" entre los NNA beneficiados con becas de estudios superiores y voluntarios que acompañan el proceso de acercamiento al mundo de la educación superior.

\section{Análisis de los Programas para reducir Trabajo infantil}

\section{Límites del Eje en la Educación}

La intervención que ambos Programas realizan en el ámbito de la Educación requiere considerar en los siguientes aspectos:
- El trabajo Infantil tiende a ser vinculado como causa de deserción, ausentismo, retraso o mal rendimiento. Por otro lado, la escuela tiende a ser expulsora más que integradora de los niños y niñas trabajadores. Los efectos que el Trabajo Infantil produce sobre el rendimiento escolar, reduciéndolo, ha sido ampliamente reconocido como uno de sus efectos más dañinos, lo que se refleja en los diversos proyectos existentes a nivel mundial diseñados específicamente para reducir este efecto (Gunnarsson et al,. 2006).

Las razones para poner atención en la educación, según los autores señalados, se refieren a que, en primer lugar, ésta es vista como pieza fundamental para mejorar la calidad de vida en países en desarrollo, a través de la erradicación de la pobreza en la vida de las personas y el mejoramiento de los recursos humanos disponibles para el desarrollo económico de los países. En segundo lugar, el impacto del Trabajo Infantil sobre la educación ha sido cuantificado a través de encuestas que miden al menos sus efectos en la matrícula escolar y la asistencia.

Los programas estudiados en esta investigación ponen un énfasis sustantivo en reducir el impacto del Trabajo Infantil en la educación de los niños/as que se benefician de sus acciones, por ello, centraremos el análisis conceptual que sigue en discutir los hallazgos específicos que se han realizado en torno al impacto del Trabajo Infantil en la educación.

- Uno de los aportes novedosos planteados por Gunnarsson (2006) es que la asistencia y retención escolar, como indicadores de medición del éxito escolar, no son necesariamente criterios exactos para estimar el impacto del Trabajo Infantil: se puede sobrestimar el impacto si no considera el aprendizaje informal (a través del trabajo o experiencias cotidianas) o la mala calidad de las escuelas. Se puede subestimar si no considera que los niños podrían auto-percibirse menos capaces de aprender porque están excesivamente cansados, o no tienen tiempo para completar sus tareas. Por lo tanto, lo que los autores enfáticamente sugieren es medir

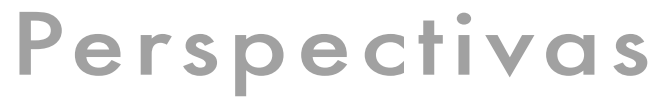


los efectos del Trabajo Infantil en lo que los niños son efectivamente capaces de hacer, en lugar de medir solamente el tiempo que pasan en la escuela (Gunnarson 2006:33) identifica dos áreas del conocimiento fundamentales de promover: operaciones matemáticas y lenguaje. La evidencia sugiere que estas habilidades cognitivas, más que los años de escolaridad, son los determinantes fundamentales en definir los futuros salarios de adultos en los países en desarrollo (Glewwe ,1996; Moll 1998)

- De allí que, en estos programas, sea fundamental resolver la tensión entre retención y rendimiento escolar: hasta la fecha ambos programas realizan una tarea centrada en la permanencia de los NNA en el sistema escolar, las razones de esto se vinculan al financiamiento, escasamente se cubre el equipo profesional para que articule escuela y familia, por lo que difícilmente se podría pensar en invertir recursos que puedan impactar el rendimiento. Lo grave de esta situación es que, como se estableció anteriormente, retención y asistencia no son indicadores que aseguren un cambio de largo plazo en la vida de esta población. Mientras no se asegure la adquisición de competencias básicas de lectoescritura y matemáticas, se perpetúa la pobreza, y en esa medida una de las causas más significativas del Trabajo Infantil.

- Los Programas atienden rangos de edades diversos y dispersos, no obstante los estudios en el área sugieren focalizar en $3^{\circ}$ y $4^{\circ}$ año básico, dado que se ha comprobado que es, en estas etapas, donde se asegura el éxito en el dominio de habilidades básicas en operaciones matemáticas y competencias en lectoescritura. Habría que realizar un esfuerzo por concentrar el apoyo escolar en estos rangos de edades, donde se asegura un nivel de éxito en el aprendizaje.

- En la línea de apoyo escolar, el Programa ProNiño privilegia la entrega de una beca, que está institucionalizada y es reconocida y exigida por los miembros del programa. Se recomienda cuidar la instrumentalización de esta transferencia económica, en desmedro de una transformación en la valoración efectiva de la escolarización.

\section{Alertas frente a las estrategias de financiamiento compartido}

El desarrollo de estrategias de Co-financiamiento no deja de ser una tarea compleja, debido a que en el caso estudiado, el financiamiento público obedece a una lógica "preventiva”, ya que, en su mayoría, la oferta del Programa ProNiño se realiza en los Centros Infanto Juveniles (CIJ) los que buscan, a través de programas ambulatorios: "prevenir la vulneración de derechos, detectar situaciones que afecten al normal desarrollo de sus usuarios, y proporcionar atención psicosocial a través de la oferta de diversos espacios de participación, a niños, niñas y adolescentes, sus familias y comunidades" (SENAME, 2006).

Por su lado, la lógica privada obedece a la responsabilidad social empresarial que pretende no prevenir, sino "curar” los efectos del Trabajo Infantil. La tensión entre la lógica preventiva y la curativa amenaza la llegada efectiva a la población objetiva del programa Pro Niño, ya que la población cautiva del CIJ no necesariamente responde a la condición de NNA trabajadores. En este escenario, junto con reconocer las bondades de un financiamiento compartido, es fundamental explicitar las tensiones que se pueden generar cuando los objetivos de los organismos que financian son distintos.

\section{Contexto de Intervención en calle}

Parte relevante de la identificación de la población afectada por las PFTI es la "detección: identificación y reconocimiento de puntos críticos (focos) donde se ejerce actividad laboral por niños, niñas o adolescentes” (SENAME, 2006). Esta tarea implica la observación de la dinámica del sector: identificación de número de niños, quiénes son, cómo se comunican entre ellos, horarios, tipos de trabajo, contacto 
con adultos, etcétera. El programa de Niños y Niñas en situación de Calle realiza esta tarea. Sin embargo, no es una estrategia de reclutamiento llevada a cabo por el Programa Pro Niño, ya que éste trabaja con población cautiva. Como ya se advirtió antes, habría que revisar las estrategias de selección de la población beneficiaria, con el objeto de asegurar el éxito en alcanzar a la población objetivo.

\section{Constituyendo Voluntariado}

El Programa ProNiño ha desarrollado una innovación que corresponde al involucramiento de voluntarios que provienen de un organismo que financia el mismo programa. Es decir, que supera el mero traspaso de fondos y pone en el escenario un compromiso personal y presencial de un colectivo con un grupo particular de niños: NNA trabajadores.

Bettoni y Cruz (2002) han advertido que en las organizaciones de voluntarios emerge un diálogo que se establece entre la participación voluntaria, la construcción de valores democráticos y de participación ciudadana, y la contribución exclusivamente económica a la solución de problemas de sectores vulnerables. Este parece ser un logro en el Programa Pro Niño. Sin embargo, es necesario prevenir otros hallazgos que estas autoras han realizado sobre el voluntariado: "Un eje importante del estudio lo constituyen las interrelaciones de cooperación, competencia o conflicto que el voluntariado ha generado entre las organizaciones del Tercer Sector” (Bettoni y Cruz 2002).

Al estudiar el caso de ProNiño, emergieron rasgos conflictivos al interior de los CIJ con la presencia de voluntarios, ya que ésta tendía a entorpecer el funcionamiento del programa, además de generar efectos discriminadores entre aquellos niños del programa ProNiño y el programa CIJ, en la medida que las actividades recreativas sólo estaban destinadas a los primeros. De lo anterior emerge una invitación a la reflexión de los responsables del Programa, en virtud del perfeccionamiento de esta innovación, a la luz de aprendizajes realizados previamente en el tema del voluntariado.

\section{Hallazgos previos}

Se propone mejorar la inclusión del voluntariado en la propuesta de intervención, a la luz de hallazgos de estudios previos donde los resultados indican:

- “Una frágil relación entre los voluntarios y las organizaciones que los acogen, donde no se establecen deberes y obligaciones claras de una y otra parte.

- Se observa que, aunque la participación voluntaria en las organizaciones es importante, aún no se han establecido, en la mayoría de los casos, políticas institucionales en cuanto a la convocatoria, a la inserción de los voluntarios en la institución y en la toma de decisiones, a la firma de acuerdos previos, ni en cuanto a los requisitos o la capacitación.

- Estos factores aparecen como claves y merecerían una revisión por parte de las instituciones para alcanzar un desarrollo sano de la acción voluntaria donde se beneficien a ambas partes. En este sentido, las organizaciones del Tercer Sector enfrentan un dilema crucial: la regulación de la actividad del voluntariado puede traer beneficios pero puede al mismo tiempo, llegar a burocratizar una tarea que es por esencia y definición no-burocrática” (Bettoni y Cruz, 2002: 10-12)

\section{Programas para reducir ESCI}

\section{Áreas de intervención}

Con la intervención directa se pretende interrumpir la explotación sexual comercial infantil y adolescente, incidiendo en la reparación e inserción social de Los NNA sometidos a esta situación de grave vulneración.

Para ello, se focalizan acciones en seis componentes dirigidos a los niños, niñas, adolescentes, las familias, las comunidades y las instituciones.

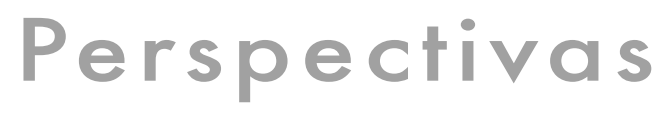




\begin{tabular}{|c|c|c|}
\hline $\begin{array}{c}\text { ÁREAS DE } \\
\text { INTERVENCIÓN }\end{array}$ & PROGRAMA RAÍCES & PROGRAMA AURA \\
\hline SALUD & $\begin{array}{l}\text { Evaluación diagnóstica: } \\
\text { - desnutrición, } \\
\text { - drogadicción } \\
\text { - alteración de conciencia, } \\
\text { Oferta de: } \\
\text { - Atención psicoterapéutica- reparatorias } \\
\text { Atención sicológica y social a la familia Los equipos } \\
\text { deben movilizar recursos públicos para asegurar la } \\
\text { provisión de servicios en salud, servicios psiquiátricos } \\
\text { y desintoxicación. }\end{array}$ & $\begin{array}{l}\text { Derivaciones a servicios médicos detec- } \\
\text { tados como necesarios } \\
\text { Atención psicoterapéutica- reparatoria. }\end{array}$ \\
\hline FAMILIA & $\begin{array}{l}\text { RAICES plantea como fundamental para el éxito del } \\
\text { proceso la existencia de un adulto significativo Su } \\
\text { ausencia enlentece notablemente el proceso de inter- } \\
\text { vención, o lo hace inviable. Para trabajar con la familia, } \\
\text { o el adulto significativo, se establece una estrategia de } \\
\text { intervención similar a la del trabajo con los niños/as: } \\
\text { CENTRADA EN EL ADULTO, de manera de recono- } \\
\text { cer y conectarse desde sus propias historias, saberes, } \\
\text { emociones, dolores y su propia sexualidad, con la } \\
\text { experiencia de dolor sufrida por sus niños/as. }\end{array}$ & $\begin{array}{l}\text { Reconstitución de vínculos significativos } \\
\text { para los niños/as. Énfasis centrado en el } \\
\text { ADULTO y una conexión personal con } \\
\text { situaciones traumáticas de los padres } \\
\text { (principalmente de las madres) que pue- } \\
\text { dan influir en la negligencia en el rol pa- } \\
\text { rental, se desarrollan factores protectores } \\
\text { y de relación padre - hijo. } \\
\text { La incorporación de los padres u otros } \\
\text { adultos significativos en este proceso } \\
\text { es lenta y no en todos los casos exitosa. } \\
\text { Sólo en un 50\%, aproximadamente, de } \\
\text { los casos se logra una intervención con } \\
\text { la familia. }\end{array}$ \\
\hline EDUCACIÓN & $\begin{array}{l}\text { Se promueve y acompaña el proceso de escolarización. } \\
\text { La Escuela ocupa un rol protector y actúa como parte } \\
\text { del proceso reparatorio, no como eje de la interven- } \\
\text { ción. }\end{array}$ & $\begin{array}{l}\text { AURA ofrece acompañamiento en las } \\
\text { Escuelas a los NNA a través del tutor y } \\
\text { del pedagogo social. Para reforzar y en- } \\
\text { terarse del proceso que vive cada niño o } \\
\text { niña, asistencia a reuniones con profesores } \\
\text { jefes, orientadores y en algunos casos } \\
\text { Directores de establecimientos. }\end{array}$ \\
\hline $\begin{array}{l}\text { CAPACITACIÓN } \\
\text { LABORAL }\end{array}$ & $\begin{array}{l}\text { La capacitación que se ha realizado en el Programa } \\
\text { no ha significado una "reconversión laboral”, ya que } \\
\text { se han ofrecido talleres que no tienen un impacto en } \\
\text { el mercado. Estas capacitaciones tienden más bien a } \\
\text { reparar y aumentar la autoestima }\end{array}$ & $\begin{array}{l}\text { El Programa ha incorporado a NNA y a } \\
\text { sus familias a programas de capacitación. } \\
\text { Se reconoce la necesidad de programas } \\
\text { flexibles para incorporar y mantener ni- } \\
\text { ños/as que requieren distintos horarios y } \\
\text { facilidad en los contenidos tratados. }\end{array}$ \\
\hline APOYO LEGAL & $\begin{array}{l}\text { El Programa es responsable de entregar información } \\
\text { sobre denuncias a la dirección regional de SENAME. } \\
\text { Hoy es necesario clarificar qué organismo es el respon- } \\
\text { sable legal de realzar este trabajo RAICES ha realizado } \\
\text { un trabajo interesante de sensibilización a los agentes } \\
\text { que intervienen en los procesos penales con relación } \\
\text { a la ESCI: Carabineros, Investigaciones, fiscalías, } \\
\text { tribunales del crimen y de menores, con el fin de que } \\
\text { se identifiquen los casos y se conozcan los recursos } \\
\text { institucionales disponibles para la intervención. }\end{array}$ & No existe formalizado este componente. \\
\hline
\end{tabular}




\begin{tabular}{|c|c|c|}
\hline SENSIBILIZACIÓN & $\begin{array}{l}\text { Trabajo de sensibilización comunitaria, debido a la } \\
\text { dispersión territorial de la población atendida, esta tarea } \\
\text { es realizada por la Oficina Central de RAICES y no por } \\
\text { el equipo de trabajo } \\
\text { Esta tarea es relevante para que la comunidad conozca la } \\
\text { acción del proyecto y reconozca la ESCIl y adolescente } \\
\text { como un problema social, que afecta a estos grupos } \\
\text { etáreos y, por tanto, prioritario en la agenda local. } \\
\text { La orientación de la política también establece que los } \\
\text { programas identifiquen recursos locales al servicio de } \\
\text { la niñez y adolescencia, y estrategias para potenciarlos } \\
\text { o adquirirlos cuando no existen. }\end{array}$ & $\begin{array}{l}\text { El Programa AURA desarrolla acciones } \\
\text { de sensibilización a través de contacto con } \\
\text { instituciones y actividades masivas, de } \\
\text { manera de dar a conocer en la población la } \\
\text { existencia de la problemática de la ESCI y } \\
\text { la forma territorial en que se organiza. }\end{array}$ \\
\hline $\begin{array}{l}\text { ARTICULACIÓN } \\
\text { DE REDES }\end{array}$ & $\begin{array}{l}\text { RAICES atiende una población dispersa territorialmen- } \\
\text { te, lo que impide realizar un trabajo focalizado en una } \\
\text { comunidad. Por ello, realiza articulaciones con orga- } \\
\text { nizaciones involucradas en la prevención, reparación } \\
\text { e inserción de niños, niñas y adolescentes en situación } \\
\text { de ESC, de manera más individualizada. }\end{array}$ & $\begin{array}{l}\text { En este Programa se señalan resistencias } \\
\text { en el ámbito policial, particularmente con } \\
\text { Carabineros, así como el sistema escolar. } \\
\text { Se indica también la dificultad general en } \\
\text { incorporar a quienes tienen dependencia } \\
\text { de drogas en programas de rehabilitación, } \\
\text { esto ocurre básicamente por la escasa } \\
\text { flexibilidad de estas instituciones. }\end{array}$ \\
\hline
\end{tabular}

\section{Las innovaciones de los programas}

\section{Relevancia de la reflexión sobre la intervención}

La generación de la política y las orientaciones técnicas para intervenir en ESCI, reflejan un proceso inductivo, en el sentido de que, a partir del aprendizaje de una organización experta en temas de explotación sexual infantil como RAICES y la posibilidad de ejecutar un proyecto piloto cuyos aprendizajes y hallazgos dieron luz a un modelo de intervención, se formuló la política nacional para combatir ESCI.

En este sentido, se puede afirmar que la formulación de la política para abordar ESCI ha sido informada por la práctica. Esto explica que el Programa de "Prevención y Atención a Niños, Niñas y Adolescentes en Situación de Explotación Sexual Comercial (ESCI)" implementado entre los años 2002 y 2005 por OIT-SENAME y SENCE, fuera uno de los primeros esfuerzos para superar este fenómeno a través de un programa de atención especializada que tenía como objetivos por un lado, reforzar el proyecto de carácter piloto de intervención integral para niños, niñas y adolescentes en ESCI, ejecutando por la RAICES y SENAME, en la Región Metropolitana (primer programa de atención en esta materia); y por otro lado, abrir una nueva experiencia en la octava región, a cargo de Clubes Juveniles MOANI, actualmente administrado por SENAME.

Los resultados contemplaron, a partir del proyecto de RAICES, la intervención terapéutica del grupo objetivo junto con un plan integral de inserción social. Y, a partir del proyecto de MOAINI, la incorporación, junto a la reparación y articulación de redes (salud, educación, jurídico-legal), la entrega de capacitación laboral de este grupo de intervención. Este centro realizó una atención efectiva, de carácter reparatorio, a 54 niños/as, principalmente de cuatro comunas de esta región.

Actualmente, SENAME cuenta con 16 proyectos de atención en ESCI, incluyendo los dos mencionados que se ocuparon como referencia para los 
lineamientos de los nuevos programas implementados.

Lo anterior refleja la relevancia de ensayar distintos énfasis para abordar el fenómeno, y reflexionar sobre esas prácticas de manera de generar conocimiento especializado sobre la problemática. Este ejercicio es el único que puede asegurar una influencia relevante en la generación de políticas y modelos de intervención. La voluntad política de aceptar este conocimiento acumulado y validarlo públicamente es el paso siguiente para asegurar esa influencia. Afortunadamente en el caso de ESCI ambas condiciones se cumplieron adecuadamente.

\section{Respecto de la Intervención Terapéutica}

La intervención terapéutica realizada en talleres de pares con los NNA afectados por ESCI, así como los talleres desarrollados para los adultos significativos, contemplan la generación de espacios "sacros”, donde emerge una importante relación entre espacio e identidad. Hetherington (1996) ha relevado la relación entre "espacio e identidad" cuando se crean experiencias terapéuticas que permiten la expresión de valores, experiencias diferentes a las que predominan en la sociedad y representan a grupos que están excluidos. Estos grupos tienden a escoger estos espacios como sitios simbólicos donde tienen la posibilidad de vivir su "otredad" de manera integrada a una identidad colectiva. Se trata de espacios simbólicos donde se reconocen experiencias comunes de los miembros y también diferentes, pero que el diálogo permite generar un sentido de pertenencia. De este modo, estos espacios colectivos actúan para compensar necesidades de identidad, pertenencia e inclusión que cruzan tanto a los NNA afectados por ESCI como a los adultos significativos ligados a sus vidas.

Hetherington (1996) hace referencia al concepto de "otro lugar" creado por Foucault (1967) y plantea que, en este otro lugar, se recrea un espejo donde los miembros del colectivo se reflejan a sí mismos, esa mirada les permite observarse y luego reconstituirse. Estos ejercicios se desarrollan en los programas estudiados y comparten, además, con la definición de Foucault (1967) la existencia de ciertas "normas de conducta" que autorizan la entrada a estos otros lugares las que se asocian a ciertos gestos, acciones de purificación, y/o de presentarse adecuadamente a un lugar que se torna sacro, una vez que están todos en disposición.

La relevancia de destacar diversas formas de conceptualizar estas prácticas de carácter terapéutico, radica en que en la medida que no se "nombren" las acciones, éstas tienden a no existir. Por ello, es fundamental que este hallazgo, sobre la forma de generar espacios, donde los sujetos de intervención reconocen cierta identidad, pertenencia e integración y condiciones que les permiten reconstituirse, encuentren ciertos referentes conceptuales que les den un ordenamiento que posibilite su transmisión para su réplica.

\section{Otras conceptualizaciones sobre el componente terapéutico reparatorio}

- $\mathrm{Al}$ indagar sobre las potencialidades de este componente, lo místico e incluso lo esotérico aparecen como instrumentos y recursos de sanación.

- $\quad$ Al respecto, existe un nuevo constructo teórico que debiera ser incorporado en el análisis y desarrollo de las intervenciones para combatir la ESCI, se trata de lo que Finke (2003) ha llamado Capital Espiritual, referido a experiencias de tipo trascendental donde se crea un especial "attachment" o apego entre las personas que comparten ese espíritu religioso o trascendental, que en gran medida amplía la capacidad de las personas involucradas para alcanzar sus fines, los que en este caso se asocian a la reconstitución, reparación y/o sanación.

- Estas experiencias trascendentales incluyen algunos aspectos asociados a rituales (general- 
mente presente en la terapia grupal de estas experiencias) que se relacionan con la biografía de cada uno de los participantes (historias de dolor o violencia, por ejemplo) los que tienden a incrementar los lazos entre los participantes y esto contribuye enormemente a evitar actividades que amenazan con quebrantar los compromisos que con esa comunidad se adquieren. Generalmente estos quebrantamientos se asocian a fugas, recaídas en el consumo o en la explotación, entre otros.

- Avances en estas materias se han desarrollado de manera más sistemática en el estudio de las religiones, por ejemplo desarrollados por Peter Berger (2003).

\section{Familias de acogida: asegurando la existencia del adulto significativo}

La existencia de un adulto significativo ha aparecido en el análisis de las prácticas casi como un axioma para el éxito de la intervención. No obstante, este punto entra en contradicción con los datos de algunas familias de los niños/as participando en los programas, que no logran ser incorporados en los procesos reparatorios. De hecho, se ha señalado en una entrevista con SENAME que la intervención a veces se entrampa bajo la ilusa expectativa de contar con la familia para ayudar al niño/a, cuando ésta en definitiva no manifiesta ninguna señal de involucramiento. Es necesario generar alternativas frente a la inexistencia de la familia.

La Corporación RAICES ha desarrollado estrategias para buscar Familias de Acogida que provienen del mundo social de los niños/as y han sido exitosas en el acompañamiento. Habría que apelar a cierta responsabilidad social en el origen del fenómeno de ESCI y por lo mismo, a la responsabilidad social en su reparación, de este modo, se facilitaría el apoyo de otros agentes que podrían constituirse en adultos significativos, compañeros del proceso.
De manera paralela y no excluyente de la búsqueda anterior, cuando no existe familia con capacidad de transformarse en protectora y acompañante del proceso de reparación, el sistema debe generar alguna estrategia de protección que responda a las características en que se manifiesta esta problemática, generalmente acompañada por experiencias de situación de calle y pautas de consumo y adicción. Se ha encontrado evidencia de que el sistema de colocación familiar no es apropiado para atender a los niños/as afectados por ESCI, así como tampoco lo han sido los establecimientos residenciales destinados a protección simple ${ }^{18}$. Debido a lo anterior, es fundamental generar una oferta residencial especializada para atender el fenómeno ESCI en coordinación con el sistema de salud.

\section{Análisis de los programas para reducir trabajo infantil}

\section{Evaluación orientada por resultados o por procesos}

La tendencia en política social y diseño de indicadores es la medición del éxito orientada por resultados en desmedro de la medición del éxito también en base a indicadores de procesos. El diseño de la política para abordar ESCI no está ajena a esta tendencia, criterios como que "al menos el $50 \%$ de niños, niñas y adolescentes, interrumpen las prácticas de explotación sexual comercial”, o “70\% de los niños/as cuentan con atención en salud y con inserción educacional o laboral, según corresponda” (SENAME, 2006) son un reflejo de esta afirmación. El problema de esta tendencia radica en que, en esta problemática en particular, el componente reparatorio fundamental de la intervención está asociado a PROCESOS, es decir a progresos en aspectos complejos de medir tales como la dignificación de la vida, la recuperación del cuerpo, la disminución de culpas, la identificación de la condición de explotado y explotador, entre otros.

18 Decreto Reglamentario 415/06 de la Ley 26061

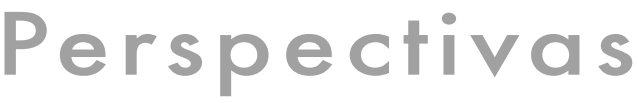


Por lo tanto, existe aquí un doble desafío, por un lado la valoración del gobierno central de la evaluación de procesos, y por otro la difícil tarea de diseñar indicadores de medición de procesos tan complejos como los mencionados.

\section{Respecto a las Capacitaciones}

El diseño de capacitaciones laborales para la población de NNA afectada por ESCI se ve desafiada por:

- La escasa escolarización de los sujetos de atención, lo que deriva en un bajo perfil de competencias.

- Un débil conocimiento de la demanda laboral orientada por oficios que asegure una "reconversión laboral” exitosa.

- La baja incorporación de los adultos significativos en las alternativas de capacitación a las que son invitados.

Por lo anterior, es fundamental que los programas interviniendo en ESCI puedan definir un perfil tanto de necesidades como de competencias respecto de esta población. Este perfil orientaría a organismos como el Servicio Nacional de Capacitación, en el diseño de alternativas de capacitación. Así mismo, el gobierno central debiera diseñar estudios que permitan conocer el estado de la demanda laboral, para orientar el diseño de las capacitaciones.

\section{La tarea del gobierno central}

La intervención en ESCI requiere de la existencia de un escenario intersectorial potente: salud, educación, trabajo son áreas que mínimamente debieran contar con una oferta especializada. El mandato sobre el trabajo intersectorial y la oferta especializada para esta población debe ser emanado desde el gobierno central. Hasta ahora, los objetivos específicos de las orientaciones técnicas para intervenir en esta área señalan que es responsabilidad de los ejecutores de los programas: “Mo- vilizar los recursos socio-comunitarios y de la red intersectorial tendiente a mejorar las condiciones de bienestar y la promoción de los derechos del niño, niña y adolescente trabajador”. Sin embargo, a través de este estudio se evidenció que existe una responsabilidad del SENAME en asegurar ciertos acuerdos básicos de operación conjunta entre los distintos organismos públicos, ya que la oferta requerida supone voluntades políticas que superan la intervención acotada de los programas interviniendo en ESCI.

\section{Respecto a la duración de la intervención}

Por último, en los relativo a los tiempos de intervención, las orientaciones técnicas de SENAME para los Proyectos de Intervención Especializados en Reparación de Víctimas de Explotación Sexual Comercial Infantil y adolescente establecen que "el proceso reparatorio contempla la atención especializada a los niños, niñas o adolescentes ingresados durante un periodo máximo de 24 meses.”

Si bien la tendencia de los planes de intervención que SENAME financia suele ser más reducidos, lo cual evidencia que para el caso de la ESCI se ha hecho un esfuerzo relevante en la destinación de recursos, surge un cuestionamiento respecto a la suficiencia del tiempo para realizar una intervención adecuada, especialmente si estos plazos incorporan el tiempo de seguimiento, y éste no se financia separadamente. Claramente, para un adecuado proceso reparatorio y de seguimiento, 2 años es insuficiente. Tanto en las entrevistas como en la literatura, se establece que la intervención sobre un fenómeno tan vulnerador, requiere al menos de tres años de intervención, para realizar un adecuado proceso reparatorio, que incluya seguimiento.

\section{Argentina}

En Argentina, es posible encontrar diferencias en la respuestas con que se enfrenta el Trabajo Infantil en el área pública estatal-provincial y en el área municipal. Estas diferencias se encuadran 
en marcos interpretativos particulares sobre el fenómeno, que determinan diferencias sustantivas en la definición de la problemática, así como en los enfoques para abordarla.

\section{Públicos estatales provinciales}

En la cartera de Promoción de la Familia ${ }^{19}$, el trabajo infantil constituye un problema "asociado directamente a la problemática general de la infancia y la capacidad o no de protección que pueda haber". En la agenda ministerial se menciona como tema prioritario la desnutrición infantil, la deserción y sostenimiento en el ámbito escolar, siendo el trabajo infantil una problemática de segundo o tercer orden, dependiendo de qué entendamos por trabajo infantil.

Se caracteriza al trabajo infantil asociándolo a "prácticas de trabajo informal en compañía de sus progenitores", ligado fuertemente "a la mendicidad y a las situaciones de calle”. Estas prácticas se vincularían con mandatos familiares orientados a la recaudación de dinero, “donde puede ser incluso castigado o exigido a hacerlo, puede entenderse como esa compañía que hace a la familia en tareas que también son de riesgo”, y la inclusión de "estrategias de niños que desvinculados de padres realizan algunas acciones específicamente en la calle".

Los programas en vigencia básicamente procuran la contención de los grupos de familias considerados como de mayor vulnerabilidad, a través de un salario de inclusión familiar de infancia. Se llega a la identificación de estos grupos por medio de relevamientos efectuados en diversos programas -aquí denominados antecedentes-, constituyendo una base de datos no homogénea ni articulada. Esto permite la asignación de subsidios o salarios de inclusión familiar según una estrategia de focalización. Se requiere de la familia beneficiada una contraprestación en términos de "disponibilidad

19 Ambas situaciones indicadas por asesora de Directora Nacional de SENAME, Octubre 2005 para la atención de los niños” -esto equivale a la retención en el seno del hogar-, en “cuidados” frente a riesgos de salud u otros, tales como asistencia a talleres de formación o capacitación (programa "Mamás Guapas"). Finalmente, hemos encontrado como otro de los objetivos de los programas vigentes, la restitución del niño encontrado en la vía pública, al seno familiar, acompañados con la advertencia de la irregularidad detectada (programa “Disposición padres”).

La hipótesis que subyace a las políticas sociales implementadas es que la única posibilidad de "torcer una pauta que es producto de una instalación reproductiva con trayectoria" consiste en sostener una pauta "de trayectoria inversa de sostenimiento": es lo que "permite a las personas esa recuperación; por lo tanto yo creo que son políticas de un plazo por lo menos diez años de sostenimiento y un sistema estable de protección social para poder notarlo". La forma de entender el Trabajo Infantil en este caso explica la naturaleza de la intervención.

En la visión, quienes cumplen funciones de Jefatura en la Subsecretaría de Protección Integral del Niño y Adolescente, el Trabajo Infantil no es visualizado como un problema social específico, sino como "una situación que está y que se ha dado siempre”. En ese sentido, las experiencias de trabajo en relación a la temática "han sido intervenciones muy desarticuladas que, o bien trabajan con el chico que está trabajando en la calle, pero es como que no se integra ese trabajo (a) la cuestión familiar”20. La escasa o nula articulación entre programas pareciera constituir una nota característica del funcionamiento institucional, sólo alcanzada a niveles micro, entre profesionales y con miras a la coordinación de un trabajo específico.

Entre las situaciones consideradas trabajo infantil se menciona el trabajo doméstico y el trabajo callejero -mendicidad, venta callejera en los

20 Las citas encomilladas corresponden a una entrevista realizada a una funcionaria del Ministerio de la Solidaridad de la Provincia de Córdoba 
semáforos-, sin llegar a especificaciones que sobrepasen este margen de categorización. Este nivel de generalidad da cuenta de que el Trabajo Infantil no es visualizado o abordado en esta institución como una problemática específica emergente en el campo social.

En relación con los procedimientos de acción que se implementan desde la Secretaría, se identifican modos institucionales que permanecen al margen de los cambios de nombre con el que se identifican los modelos políticos gobernantes:

"La modalidad de la institución ha sido siempre, cuando se han detectado chicos en situación de trabajo infantil en la calle, colarlos en institutos. Y luego se trabaja para el egreso de estos chicos. Hay otras situaciones que no tienen que ver con el trabajo infantil, que la estaría trabajando un área que es Disposición Padres, pero refiere únicamente a chicos que son encontrados en la vía pública, o porque están con alguna sustancia tóxica, ya sea droga o alcohol, y no quedan a disposición de la justicia de menores sino con los padres. En una segunda ocasión, en que los encuentren en esta situación, ahí sí quedan judicializados. Así, sería una intervención ciertamente preventiva, pero que no refiere a chicos que estén en situación de trabajo."

La invisibilización que opera a nivel institucional se realiza suprimiendo la categoría "trabajador” y operando desde otras nominaciones más funcionales a la programática vigente: niños en situación de calle, niños encontrados en la vía pública, niños maltratados, etcétera. La invisibilización -vía la negación de la existencia del problema- pareciera ser el mecanismo que mayor funcionalidad otorga al sistema, al posibilitar la reproducción de modos de acción institucional de larga data.

Resumiendo, es posible señalar que en la visión de los actores públicos estatales provinciales el trabajo infantil se invisibiliza como problemática al quedar subsumido en categorías que describen con mayor funcionalidad su abordaje. Esto permite el mantenimiento de un modo de acción institucional que pervive más allá de los cambios de nombres, reproduciendo políticas asistencialistas focalizadas.

\section{Públicos estatales municipales}

Para identificar los programas sociales o acciones implementadas para enfrentar el trabajo infantil en el área pública estatal municipal, se entrevistó a funcionarios pertenecientes a la Dirección de Educación y a la Dirección de Familias Vulnerables.

En la visión de los funcionarios municipales que se desempeñan en la Dirección de Educación ${ }^{21}$, el trabajo infantil constituye un problema social en emergencia, en tanto la profundidad de la crisis económica y social, pone en evidencia la importancia que el aporte -monetario o no monetario- del niño/a tiene para la economía familiar.

Esta problemática social, se manifiesta en el impacto que tienen las prácticas de trabajo infantil realizadas en horario extraescolar dentro del ámbito escolar: en la asistencia, el rendimiento, la incidencia en los resultados de promoción.

Estos funcionarios identifican como prácticas de trabajo infantil:

- El trabajo doméstico -cuidado de hermanos, realización de tareas domésticas en la vivienda;

- Trabajo fuera de la casa y en compañía del padre en la calle -cartoneros-;

- Trabajo fuera de la casa y sin compañía del padre en la calle -limpia vidrios-;

- Trabajo en asentamientos económicos, con

21 Las citas corresponden a la entrevista mantenida una coordinadora de un Programa de la actual Subsecretaría de Protección Integral del Niño y Adolescente; lo que significa una posición de Jefatura, pero de personal de planta y por lo tanto no es un cargo político. 
empleador -quintas, cortaderos de ladrillos-. Este último estaría encuadrado como explotación, dada la inadecuación entre la paga y el trabajo, así como las condiciones en que se realiza y el sujeto empleado para hacerlo.

"Hasta tienen un horario determinado, porque, primero van al colegio, y después salen a cirujear con el padre o con la madre”.

La problemática del trabajo infantil emerge interpelando las prácticas institucionales:

“¿qué hacemos nosotros desde la escuela, si nuestro objetivo es lo pedagógico? Y ¿cómo hacer para que estos chicos no abandonen la escuela, y puedan cumplir con las tareas y no estén cansados, y que puedan hacer las dos cosas (estudiar y trabajar), porque en muchos casos, contribuyen al sustento del hogar.”

Al mismo tiempo, es visualizado como factor que puede poner en riesgo el desarrollo integral de la persona: “(los niños) están en etapa de desarrollo. O sea, lo pueden hacer, pero ¿cómo será ese cuerpo en el futuro?”

Para el caso de los niños que trabajan en situaciones de explotación, se preguntan: "en estos casos hay un empleador, que no es el papá que lleva al chico a juntar cartones, sino que hay un empleador que es, o bien el quintero o bien el dueño del cortadero de ladrillos, quien emplea al niño".

En este conjunto de afirmaciones es posible resaltar que lo que predomina en este discurso, es una lógica de abrirse al problema, de identificar situaciones diversas, de dejarse interrogar, antes que de cerrar el análisis.

En la visión del funcionario de la Dirección de Familias Vulnerables ${ }^{22}$, el Trabajo Infantil “es una

22 En adelante, las citas encomilladas corresponden a una entrevista realizada al subdirector de la Dirección de Educación de la Municipalidad de Córdoba y a su equipo técnico. problemática crítica que amerita ser absolutamente prioritaria en la política social”. La categoría "problemática crítica” es empleada con referencia a la vulnerabilidad en que transcurre la vida cotidiana de los niños y se estructura la personalidad. El trabajo infantil condiciona "el nivel de conciencia que ellos desarrollan, digamos, de conciencia limitadísima, en relación a qué es lo que implica su situación laboral”.

Define el Trabajo Infantil como "una práctica que busca orientarse a un componente económico, encuadrada en una estrategia de subsistencia familiar". Cumple un rol social relevante en tanto denuncia la "degradación y mediocridad de los valores que van cohesionando la sociedad”.

La clasificación del Trabajo Infantil enunciada por el funcionario se construye según el lugar donde se desarrolle y el género predominante:

- Callejero -donde predominan mendicidad, limpiavidrios, cirujeo, especialmente llevada a cabo por varones-

- Doméstico -donde predominan las mujeres-

- Aquel donde participa la familia completa, sin distinción de género.

E incluye una consideración en función del régimen de obtención del ingreso:

- Situaciones de explotación

- Cuentapropismo

En relación al impacto que produce en la subjetividad del niño/a, es considerado simultáneamente como una realidad que incluye elementos positivos y negativos. Por una parte, contiene un "componente proactivo", que opera como configurador por estar dotado de normas: "es una oportunidad para la resiliencia, para, digamos, potenciar valencias de un sujeto en orientarse a la inclusión social.” Tomando como caso ejemplificador las tareas domésticas, el trabajo puede constituirse en una

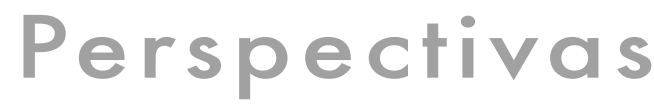


instancia formativa, constructora de identidad, contenedora y potenciadora de saberes, que puede conjugar lo lúdico y lo laboral. Por otra parte, "lo vulnera, o lo afecta más o menos, pero siempre lo afecta, nunca lo suma, en ese sentido”. Puede constituirse en una instancia que conspira contra el desarrollo del niño/a.

La existencia y permanencia del trabajo infantil en la calle se vincula a distintos factores: por una parte, a la ausencia del Estado y al desmantelamiento efectivo de instituciones que eran visualizadas como dispositivos de poder para el control de niños (Consejo del Menor) "(la calle)es una zona de terreno liberado, y la única institución que tiene presencia es la policía”. También se explica a partir de las prácticas familiares de sustitución de ingresos relativamente recientes (padres que salen con sus hijos a trabajar) y la existencia de pautas culturales naturalizadas, en el caso de núcleos familiares de larga trayectoria en esta práctica.

Las acciones que se están desarrollando actualmente para la atención de esta temática, definida como problemática crítica, consisten básicamente en un relevamiento censal orientado a la confección de una base de datos que permita conocer la magnitud y características del fenómeno.

Las herramientas consideradas idealmente para trabajar la problemática consistirían en el diseño de una política de sustitución de ingresos y fortalecimiento familiar, dado que "siempre las familias tienen... están atravesadas por lo económico más algo más, más uno como mínimo. (...) entonces, para lograr que esa familia desarrolle, un proyecto de construcción de calidad de vida o familiar, nosotros tenemos un plan de fortalecimiento familiar, sobre la base de ese diagnóstico hecho con la familia, que también está vinculada a las causas, a los objetivos que persiguen en sus actividades, bueno, hacemos uno para cada familia”

\section{Análisis de las acciones y concepciones para reducir trabajo infantil}

En los argumentos que construidos a nivel público estatal provincial, para dar cuenta de la existencia del Trabajo Infantil como problema, se otorga un lugar central a factores de orden subjetivo-relacional y especialmente a aquellos ubicados en el ámbito de la familia. Ello se evidencia tanto en el plano de los discursos construidos por los funcionarios de este nivel para dar cuenta de la problemática, como en el plano de las acciones focalizadas que se llevan a cabo desde los distintos programas asistenciales en vigencia.

"Creo que hay una desorganización tanto de la vida cotidiana y de la vida institucional que... deteriora aspectos vinculados a su crecimiento y desarrollo. Hay una grave situación en relación a sus padres, es decir, sus contextos de convivencia (...) El deterioro más grave es el que se vive desde ese ámbito”. (...) Esta crisis genera mendicidad infantil, en los padres, especialmente en las madres, en la búsqueda de recursos básicos de subsistencia y genera también en algunos casos rupturas de vínculos”.

Se podría considerar que esta visión se ajusta a la tendencia que considera que el niño/a debe ser protegido en tanto su condición principal es la de ser un "menor necesitado de tutela"; esta tutela le corresponde centralmente a la familia y, ante el incumplimiento de los roles paternos, debe realizarse bajo la supervisión del Estado. En consonancia con este planteo, el niño/a se convierte en un ser socialmente invisible, sin valía propia. La preocupación central evidenciada, consiste en la restitución del niño/a a aquellas instituciones socialmente consideradas responsables de su cuidado y socialización:

“los niños están en situación de calle, no están insertos en las instituciones específicas, en lo estimado como adecuado para su edad, que es la escolaridad, el contexto familiar de convivencia,

\section{Perspectivas}


como lugar de seguridad, y el niño adolescente desertando de la escuela y con acciones o iniciaciones en la delincuencia”. (...) “aunque sea un trabajo y no explotación, es explotación el trabajo infantil”.

Por otro lado, la hipótesis descrita sobre las políticas sociales implicaría la aceptación de dos términos diferenciados: por un lado, la existencia de una pauta social que pareciera reproducirse indefectiblemente en los ciclos vitales de los sujetos y que se exterioriza en la irrupción del niño en espacios públicos -la calle, el ómnibus, las esquinas, las plazas, el pórtico de las iglesias-; y, por otro lado, la apelación a la acción estatal, efectividad en los programas de las políticas sociales, como herramienta necesaria para la rectificación de esta trayectoria, para su reencauzamiento.

Pareciera sostenerse que "si existe esta pauta y media la acción estatal, es posible revertir esta trayectoria”. En esta hipótesis, el niño/a no aparece como sujeto: queda invisibilizado, desplazado y reemplazado por el lugar que ocupan los adultos, ubicados en polos antagónicos: unos, los padres, culpabilizados ante el incumplimiento de sus responsabilidades familiares; otros - los funcionarios del Estado, a través de sus agencias y programascumplen el papel de garante del orden, de control de la anomia social, de gran Tutor. Se actúa manteniendo en vigencia prácticas amparadas en la derogada ley 9053, de Protección Judicial del Niño y el Adolescente, pero aún más, con reminiscencias del discurso fundacional de las instituciones que se ocuparon inicialmente en nuestra provincia de la niñez.

El trabajo infantil no pareciera, en este nivel, representar una entidad específica; es definido como una práctica que implica la compensación de ingresos al seno familiar en compañía de los padres, que supone la existencia de una situación de explotación y ruptura de vínculos parentales, por lo cual se considera como un obstáculo para el desarrollo del niño, al favorecer su desafiliación a las instituciones socialmente consideradas como constructoras de su identidad -familia y escuela-.
En razón de ello, se actúa mediante programas que asistan al núcleo familiar, tanto en lo que respecta a la obtención de un ingreso -no vía un trabajo estable, sino como compensación económica- así como en la rectificación de representaciones -vía capacitación y reflexión en talleres-.

La judicialización aparece como una instancia paralela y desarticulada, que opera apelando a procedimientos enmarcados dentro del paradigma de la situación irregular.

En el ámbito público estatal municipal, se detecta una consideración de estas prácticas como trabajo infantil, con entidad propia y rasgos definidos. Es visualizado como factor integrado a la constitución de la subjetividad del niño/a y se lo incluye discursivamente en relación al desarrollo de la cultura del trabajo, lo que amplía la comprensión del fenómeno.

En este nivel, el trabajo infantil existe como problemática emergente que impacta en la sociedad en general, y en la institución escolar, de una manera aún no suficientemente delimitada. Es dimensionado como una práctica que contribuye en lo doméstico a la sobrevivencia del núcleo familiar, a partir de la asunción de roles al interior de la familia, o con la participación en actividades que impliquen la obtención directa de ingresos económicos. En algunos casos, el trabajo infantil está asociado a la existencia de una situación de explotación, por lo cual se considera como un factor de riesgo para el desarrollo del niño/a. En razón de ello, se están llevando a cabo acciones tendientes a dimensionar la problemática, a fin de generar respuestas políticas e institucionales adecuadas a la realidad del niño/a.

Se podría conjeturar que los funcionarios públicos estatales municipales sostienen una visión que conjuga aspectos típicos de la posición abolicionista -la consideración del niño/a como ser necesitado de protección y cuidado frente a situaciones de riesgo-y de una valoración crítica -el niño/a como sujeto de derechos, que construye su subjetividad 
en la interacción conflictiva con las circunstancias que lo rodean y aprende del contexto estrategias para la resolución de sus necesidades-.

Las acciones que se desarrollan desde el ámbito municipal, dan cuenta de la búsqueda de articulación entre diferentes actores locales (la Universidad, las instituciones escolares, los padres de familia). No se encontraron acciones específicas orientadas al abordaje del niño/a trabajador en el campo educativo, ni programas que actualmente se estén desarrollando en miras a la consideración de esta temática. Sí se percibió una sensibilización que puede conducir a tal desarrollo.

Desde una perspectiva más general y asociada al impacto de las acciones y programas existentes en el caso Argentino, donde el desarrollo de la política ha sido lento en un contexto social, político y económico, complejo y difícil, el análisis se ha desarrollado en función del conjunto de información recopilada como un todo, ya que en el desarrollo de las respuestas se nombran distintas acciones y/o políticas que por acción u omisión, o como propuesta o como crítica, son identificadas por su relevancia para el abordaje del trabajo infantil. Al realizar dicho análisis, se han identificado como relevantes: la política educativa, la política económica, las políticas sociales que ponen el acento en lo asistencial y las que lo hacen en el control/ represión.

Más allá del signo positivo o negativo con que se caracterizan las acciones u omisiones de dichas políticas, una primera afirmación es que la dimensión educativa y la económica son reconocidas como constitutivas del trabajo infantil y que las perspectivas asistenciales y represivas están presentes en las acciones predominantes vinculadas al mismo.

\section{La política educativa}

De la información analizada, se puede afirmar que el tema trabajo infantil, no está presente en las políticas educativas impulsadas a nivel provincial desde el Ministerio de Educación de la Provincia de Córdoba: "no hay particularmente en educación líneas de acción directa para ese problema social que es el trabajo infantil. No es abordado ni en la escuela, ni en el currículo, ni por la gestión directiva” (ex funcionaria provincial).

Si bien no existen políticas educativas que tengan en cuenta al trabajo infantil como un tema a estudiar y abordar, en este estudio aparece como un problema que necesita ser abordado. En definitiva, esta demanda surge tanto de los docentes, como así también en algunos casos de los padres de niños/as trabajadores.

El reconocimiento de la cuestión no se da espontáneamente, sino vinculado a la presencia cada día más visible de los chicos en las calles de las zonas céntricas de la ciudad. Así, al volverse evidente, impacta con mayor fuerza instalándose como problema en la opinión pública y es tomado por los medios de comunicación. Recién en este escenario es que las escuelas empiezan a decir: "la problemática de los chicos que están trabajando en la calle: escaso rendimiento, escasísimo pobre, muy pobre... dispersión, mucha violencia. Y eran, justamente, esos chiquitos que nosotros veíamos en la calle los que en la escuela también tenían problemas. Entonces, las maestras decían: “¿Qué hacemos con estos chicos? ¿Cómo nos ayudan ustedes? ¿Cómo los tratamos? (profesional del ámbito provincial)

Ante el problema ya instalado, emergen diversas expresiones que refieren a un abanico de "reacciones" que van desde el interrogante que se hace cada docente a nivel casi individual, en el propio espacio del aula. Por ejemplo, se plantea en la entrevista a la Unión de Educadores: "Pero sí sé que las compañeras... he escuchado a algunas de urbano-marginal, tienen ese registro, y conversando con ellas es como que hay adaptaciones que tienen que hacerse". Otro tipo de interrogantes expresa el inicio de una búsqueda un tanto intuitiva y hasta errática de respuestas, pero que de todos modos, indican una puesta en movimiento. Tal es el caso de la Dirección de Educación de la Muni- 
cipalidad: "Nosotros también habíamos pensado en implementar desde la escuela algunos tipos de actividades, como talleres para los padres donde se les pueda informar con especialistas; trabajar más que nada en los deberes y derechos de ellos y de los niños” o cuando se cuestionan: “¿Qué hacemos nosotros desde la escuela, que nuestro objetivo es lo pedagógico?.¿ Y cómo hacer para que estos chicos no abandonen la escuela?”

En estas búsquedas, vuelve a expresarse una fuerte asociación entre trabajo infantil y fracaso escolar, lo que permite corroborar que estarán marcando las estrategias de intervención que surjan desde el ámbito educativo: "El objetivo del equipo es trabajar con el fracaso escolar; entonces, en las entrevistas individuales, con los adultos, por ahí, sale el tema del trabajo".

Ante esto predominan modificaciones centradas exclusivamente en lo pedagógico, como por ejemplo: "lo que tendría que modificar la escuela sería: tener aulas con menos alumnos, una pareja pedagógica que estuviese trabajando, se me ocurre, porque no está fácil; y porque hay cuestiones que tiene ver con la enseñanza y son las que se imparten con la tiza y el pizarrón, por decirlo así” (gremio docente)

Otro tipo de elementos, que apuntan más a cuestiones de fondo, marcan la permanencia de visiones liberales de la educación, que descontextualizan al sujeto que aprende de los condicionamientos político-económicos que marcan su cotidianeidad, lo que necesariamente impacta en desvalorizaciones y estigmatizaciones.

Lejos de cuestionar problemas de fondo, este tipo de perspectiva perpetúan un sistema que continúan depositando las posibilidades de superarlo en los sujetos: “recién en el 99' el tema de la pobreza y la escuela, ahí se empezó a instalar, quizás un poquito antes, pero siempre con un aire optimista, no?, esto de que bueno, son pobres pero van a poder salir de la pobreza si se empeñan, si son estudiosos, si les damos becas, si los sacamos del lugar en donde viven, toda esta cosa” (ex funcionaria provincial)..
Otro aspecto que la misma funcionaria critica respecto a las acciones del gobierno provincial, es la preeminencia de criterios regidos por el marketing y el rédito electoral, priorizándose como consecuencia, la concreción de estrategias que se asientan en la difusión con impacto en la opinión pública de obras vacías de contenido, lo que se vincula con la corrupción instalada en la función pública y en la política: "pasa todo por el presupuesto, por los recursos que se le asignen, y se le asignan a aquello que se puede mostrar, por ejemplo, la construcción de las escuelas, el comprar libros, comprar útiles, comprar computadoras, que cuando se inaugura la escuela se llevan las computadoras, cuando se van los que fueron a la inauguración se sacan las computadoras y se llevan a la próxima escuela que se va a inaugurar”. (ex funcionaria provincial).

Asimismo, varios de los entrevistados, ya sea en el ámbito provincial como municipal, reconocen que las modificaciones realizadas en los últimos años en la Política Educativa, muestran un retroceso en la relación entre la educación y el trabajo, que había sido una asociación muy fructífera en la historia argentina, plasmada en la Educación Técnica, que tuvo un amplio desarrollo e impacto simbólico, en la construcción de la identidad nacional: "era una barbaridad haber sacado el eje del trabajo del horizonte educativo, porque fue como un eje aglutinante en toda la constitución del estado argentino, no de la constitución del papel, quiero decir, de la institucionalización de nosotros como país, el trabajo por más que fueron lo liberales que lo hicieron, tenían como bandera la educación y el trabajo, que el neoliberalismo borró por completo la relación entre la educación y el trabajo”(ex funcionaria provincial)

“lamentablemente, las escuelas de oficio, demás tendrían que tener una política... es una preocupación de nuestros docentes que el niño que termina la primaria y no tiene la posibilidad de recibir una educación técnica, que haga carreras cortas, de 2 años; como, por ejemplo, para ser un buen carpintero...” (equipo municipal)

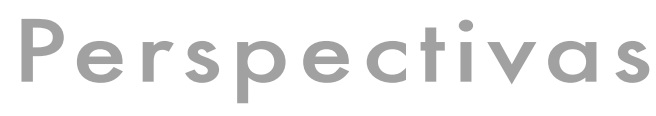


Finalmente, se comparte entre los distintos actores la ausencia de una política educativa clara respecto al trabajo infantil. Se identifican algunos intentos de abordaje desarticulado, impulsados a través de esfuerzos personales, que intentan una articulación en terreno: "nos vemos aún con dificultades... ya lo hemos planteado acá, y nos han dicho: "bueno, sí, empiecen”. Ahora la idea es coordinar acciones con otras instituciones que estén trabajando en el barrio.. necesitamos ayuda, hay que armar una red" (equipo municipal)

\section{La política económica}

Existe una tendencia a articular el crecimiento del trabajo infantil con problemas de la distribución del ingreso, que impacta generando brechas cada vez más grandes en la población, como así también, en los sectores más vulnerables que apelan a estrategias de sobrevivencia y de incremento de ingresos en las que se incluyen los niños/as, como proveedores de la economía familiar.

Los énfasis en este aspecto son variados, también se diferencian respecto al lugar que se le asigna en la explicación del trabajo infantil. En el caso de la Dirección de Educación de la Municipalidad, se refieren a este aspecto señalando que: "son familias totalmente excluidas del sistema y muy necesitadas. Además, para estas familias, estos niños significan el sustento"...”en una situación de pobreza extrema, que lleva a esto"...”Es la parte perversa del sistema económico, que me permite esclavizar a unos para quedarme con la mayor parte del capital; aún más ahora, con esto del neoliberalismo y que cada vez son menores los grupos que concentran el poder económico”

En el caso de la funcionaria del ámbito de Solidaridad de la Provincia, se habla de pobreza y se enfatizan aspectos socioculturales y vinculares que se asocian a la pobreza: "hay una descontención clara en términos vinculares, insisto más, en términos vinculares de la institución, no hay capacidad de las instituciones de responder a tamaña segregación, no hay capacidades de las familias por que esta destrozada, y hay una violentización generalizada yo creo que la secuelas de la crisis, del empobrecimiento, recién se están visualizando algunas de las consecuencias"

Otras entrevistadas del ámbito provincial enfatizan en que el trabajo infantil existe porque existe la pobreza: "dicen las mamás: "no tengo trabajo, yo tengo 9 para cuidar, tengo 3 bebés...” Entonces, los chicos son los únicos proveedores; lo que sabemos, son los proveedores familiares..."es una manifestación de la pobreza, es cómo se manifestaba la pobreza, por eso salían a trabajar”

Desde la sociedad civil, se enfatiza que la primera explicación y por lo tanto la primera estrategia para resolver a fondo el problema "es redistribuir la riqueza... el problema es la pobreza, es un tema complejo para hablar, pero el problema es la pobreza y no el trabajo infantil”.

Esta lectura del problema lleva a algunos entrevistados a reconocer en el ingreso universal para la familia, una estrategia de intervención significativa: "la recuperación de ciertos marcos estables de ingresos básicos que permitan que crezcan tus hijos... tiene que haber un apoyo básico para la familia, que tiene que ser para mi de tipo universal, permanente, a largo plazo, sin ningún tipo de contraprestaciones de trabajo" pero ello no aparece plasmado en ninguno de los programas concretos que se llevan a cabo. Sí en cambio, desde la Dirección de Grupos Vulnerables de la Municipalidad, existen estrategias de abordaje del problema con características de micro emprendimientos productivos, de forma focalizada y con una población reducida.

Entonces, si bien algunos actores han recuperado en sus discursos la importancia de retomar la educación para el trabajo, ninguno de los actores representantes del Estado ha planteado la necesidad de abordar la problemática a partir de políticas de empleo genuino.

\section{Perspectivas}




\section{Políticas Sociales: asistencialistas y represivas}

En los dos ámbitos gubernamentales estudiados (provincia y municipio) y en la sociedad civil, existe coincidencia respecto a la negación y ocultamiento del problema por parte del Estado, cuando deben identificar qué se hace o qué políticas sociales se dirigen a abordar el trabajo infantil. Estas opiniones parecen poner el énfasis en algo que no se quiere o no se está en condiciones de mirar; pero también, se hace referencia a la ausencia del Estado como contexto que ha favorecido o genera la emergencia de ciertas prácticas como el trabajo callejero, ya que éste se ha instalado de la mano del crecimiento estructural de la pobreza e indigencia.

"Por ahí, es como una práctica negada”...”Creo que está sectorizado acá en Córdoba, hay tantos temas, es medio invisibilizado”...”Me parece que es como que hay una cuestión de que se oculta, más que nada”..."en particular el callejeo esta absolutamente vinculado a la ausencia del Estado” ...

Otro tipo de referencias -en el caso de la entrevistada del gremio docente- a la invisibilización, se liga más a la idea de naturalización del trabajo de los niños/as en su ámbito familiar y comunitario cercano: “acá se ve como más invisibilizado y en lo rural se ve como más incorporado a lo familiar, de alguna manera también se ve invisibilizado, ¿no?”

Otro llamado de atención se vincula con la visión de cuáles son las políticas sociales necesarias, reconociéndose que no existen Políticas Sociales Integrales que aborden el problema, es decir que la invisibilidad del mismo, se registra principalmente en los niveles de planificación del Estado y la consecuente asignación de recursos para abordarlo, “específicamente de cómo evitar el trabajo infantil, iniciativas ligadas a trabajos específicos, yo no tengo conocimientos, o sea no puedo decir algo concreto, puedo hablar de las tendencias generales, de lo que uno escucha, pero vinculado directamente al niño que trabaja, no. Honestamente, no sé si en justicia estarán encarándolo”...(funcionaria del
Area social e infancia de la provincia)

“a nivel Estado, en la Argentina, ¡no conozco ninguna práctica buena, ninguna!, yo te puedo decir, ninguna" o ... "el principal obstáculo, el lugar que ocupan las políticas sociales, no hay una vocación realmente transformadora hacia las prioridades que operan, es lo macro" (Funcionario municipal del Área de Grupos Vulnerables)

Vinculado a lo anterior, lo que se reconoce es la intervención estatal ante casos explícitos, evidentes, graves o que toman estado público y por lo tanto con una perspectiva focalizada, puntual y de control de una situación límite: "el Estado no hace básicamente nada; es decir, los saca pero no hay... Digamos, hay una intervención en aquellos casos graves, cuando se ve que la familia no puede, cuando hay 10 niños, que la mamá nos decía: "no puedo, los chicos se me escapan directamente y vuelven a las 7 u 8 de la tarde y yo...”...”en los 7 años que estuve en el gobierno, nunca se ha planteado la cuestión de los niños trabajadores. (profesional del área Social del gobierno de la Provincia de Córdoba)

Una perspectiva de lectura del problema muy común -y que se traduce en perspectivas de estrategias de intervención-, es aquella que vincula la "mendicidad" o pedido reiterado de asistencia, con trayectorias familiares que parecieran reproducirse en sí mismas, sin incorporar en el análisis los impactos que en ellas dejan las políticas sociales, en extremo asistencialistas y focalizadas, de los últimos 20 años en Argentina.

"Yo le llamo mendicidad, porque es un término que se empezó a aplicar hace poco, yo le llamo mendicidad a tratar de... es como una especie de estrategia de sobrevivencia que significa pasar por todas las áreas de gobierno pidiendo cosas y terminar en las esquinas y siguen pidiendo cosas, es decir, empiezo por el hospital, sigo por el dispensario de mi barrio, pido la leche, paso por el ministerio y pido un subsidio, voy a otro lado y pido remedios, voy a otro lado y pido los cospeles, me voy con el 
chico y vendo las cosas, es decir, hay yo diría, un trayecto de obtención de recurso basado en esto, que yo le digo... la mendicidad, tocan todas las puertas posibles... donde los niños participan activamente, y son muchas veces la excusa, el motivo de eso, y obviamente la situación de calle de los niños que es una cosa que ya esté definida, pero yo le llamo... digamos, a esta mamá mendiga, que tiene que andar con ciertas cuestiones asistenciales muy marcadas, íntegramente fragmentada, que en un lado te dan la leche en otro un plan, en otro..., entonces esa mamá que hace ese recorrido..."

(Funcionaria del Area Social del la provincia de Córdoba).

En las expresiones de la funcionaria, se menciona este perfil de políticas sociales, desde un sesgo de crítica, enfatizando sobre el comportamiento o estrategia familiar como algo ya instalado, como un dato naturalizado y que caracteriza "per se" a un tipo de familia, sin poder reconocer que -en primer término- la reproducción de estas estrategias familiares son consecuencia de la lógica focalizada y asistencialista de las Políticas Sociales predominantes en los últimos años, que instaló la fragmentación en el abordaje del problema y lo atendió desde la idea de provisión de los recursos con una lógica desarticulada y netamente clientelar. Invertir los términos de la explicación sobre un problema tiene consecuencias graves tanto en la comprensión como en el diseño y abordaje de estrategias de intervención y, en este caso, podemos resaltar un modo más de fortalecer un histórico problema en las políticas sociales dirigidas a la pobreza: la culpabilización de la víctima.

Otra expresión de la concepción anterior es la valoración negativa de las familias que no tendrían o habrían perdido los valores y las prácticas de cuidado y protección de sus hijos/as. Ello se expresa en el surgimiento y sostenimiento -en la actualidad- de Programas de Políticas Sociales, que contemplan un aporte económico a la familia vinculado a una contraprestación que incluya por ejemplo, el cuidado de la salud y la educación de los niños/as. Ello además conlleva una mirada de los niños/as lejana a la perspectiva de sujetos de derecho, y los ubica como elemento de control para garantizar la permanencia de su familia en el Programa: "Es a través de este programa, que se las contiene con un salario de inclusión familiar de infancia, como contraprestación digamos, de al cuidado de los niños/as, y a la propia capacitación de las mamás o la inclusión en algunos procesos conjuntos de reflexión”... "son cincuenta pesos por niño, un poquito mas alto, por ejemplo que el plan familia, que varios se han pasado por que aparentemente el plan familia ha aumentado un poco por niño, y a algunas por el plan jefe se le agregaba por niño" (Funcionaria del Area Social provincial)

La totalidad de los programas que se mencionan vinculados a este tema son de carácter focalizado y asistencial; tanto a nivel provincial, como es el caso de los Centros de Cuidado Infantil, que enfatizan su atención específicamente en el tema nutricional, como el Programa "Madres Guapas" que va dirigido a apoyar a las madres solas, cuyo hijos/as podrían caracterizarse como "niños en situación de calle”.

A nivel municipal, con la misma lógica de focalización se implementa un censo para detectar los casos que se encuadran como Mendicidad Infantil, abarcando "una población de cero a doce, si hay una mamá que pide para un nene de dos años, nosotros intervenimos, tenemos una proyección de setecientos, vamos a ver si finalmente son setecientos niños, pero nos está yendo espectacular con el censo, porque el nivel de receptividad es altísimo, entonces tenemos nombre, apellido, numero de documento, dirección, teléfono”.

En este programa municipal, se incorpora el componente económico y el de fortalecimiento familiar, que apunta a incluir a la mamá en un emprendimiento productivo acorde a sus expectativas y capacidades, que le abra otras perspectivas de canales de ingreso económico familiar. Si bien estas 
estrategias incorporan un componente promocional al asistencial, no deja de ser una política focalizada, en la que un aspecto asistencial-económico subyace junto a un aspecto socio-educativo.

De las entrevistas analizadas, surgen expresiones críticas respecto a la corrupción y utilización de políticas sociales con un objetivo de rédito político electoral, primando en las acciones, el objetivo principal de realizar propaganda política del gobierno: "y la acción social está como en segundo o tercer plano; relegada casi a ser un factor de marketing, de cuestiones simbólicas que aunque no tienen impacto, por lo menos te permiten decir: "no, pero yo me preocupo por el tema, estoy en eso"( funcionario municipal) o "Se dieron 3000 becas de 75 por mes en ese momento, en el año 2000 por qué se hace en ese momento histórico y político? Y las causas siempre son... sacarse la foto, ¿no? Sacar la foto y mostrar, digamos, el gobierno" (profesional del Area Social de la Provincia)

Algunos entrevistados tanto de organizaciones públicas, como así también de organizaciones sociales, recuperan como referencia del tema trabajo infantil, la experiencia realizada por la Luciérnaga ${ }^{23}$ : "La Luciérnaga, en una primera instancia cuando salió este programa, fue uno de los organismos que mas nos ha aportado en este ámbito información sobre este tema" (funcionaria provincial)Así mismo, el propio coordinador de dicha iniciativa, hoy funcionario municipal agrega: "La Luciérnaga dejó una marca en el sentido de que a los chicos, digamos adolescentes y jóvenes, se los podía promover desde el trabajo"

Pero hay que llamar la atención respecto a que a pesar de reconocer experiencias y propuestas de intervención evaluadas de forma positiva, no se haya podido establecer una articulación que

23 Las citas entrecomilladas corresponden a una entrevista al funcionario que está a cargo de la Dirección de Familias Vulnerables de la Municipalidad de Córdoba y que fue convocado a ocupar dicho lugar por un reconocimiento público a su trayectoria. favorezca intervenciones coordinadas desde las diferentes áreas ministeriales, o dentro de la misma institución: "Ni de relacionarse, estoy hablando del Ministerio de Educación, estoy hablando con el Ministerio del gobierno, por ejemplo, con los Ministerios que antes llamaban de Desarrollo y Acción Social, a ver qué están haciendo, como pueden coordinarse acciones" (ex funcionaria de Educación de la Provincia)... "como siempre ha ocurrido, han sido cuestiones muy desarticuladas, intervenciones muy desarticuladas, que o bien trabajan con el chico que está en la calle, pero que no se coordina con el equipo que está más cerca de la familia en el barrio”... (Jefa del Area Social de la Provincia)

En síntesis, las políticas focalizadas, asistencialistas y clientelares; la búsqueda de rédito político a través de estrategias de propaganda, como así también la desarticulación entre las diferentes áreas que abordan el problema, lejos de constituir una respuesta real del Estado a través de Políticas Sociales, abren el espacio para que surja otro tipo de intervenciones, las políticas ligadas a la seguridad-represión. Esta situación continúa manteniendo el paradigma de la situación irregular, en las instituciones y las prácticas sociales, lo que oculta el verdadero problema y favorece la lógica de traspasar el mismo, a las estrategias de judicialización de la pobreza y la represión policial.

Ante la ausencia de Políticas Sociales Integrales con capacidad de brindar atención adecuada a las familias, en la tensión de su función de control social y protección de los ciudadanos, el Estado asume un rol ambiguo entre asistencia y represión, reforzando el ocultamiento y la negación de la problemática, como evidentemente de las causas que la originan: "te das cuenta de que son para erradicar el trabajo por un lado, y por otro, para sacar al chico de la calle, que no estén mendigando o molestando a los autos, demorando los semáforos... a eso me refiero” (Foro Intersectorial)

Una sociedad con grandes diferencias sociales y

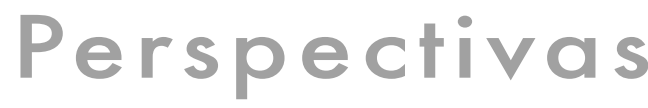


con una creciente dualización social, que cambió la estructura social en los últimos 30 años, y un escenario de políticas sociales como el descrito -0 sea contextos político institucionales democráticos pero con débiles garantías de los derechos sociales y económicos- es una mala combinación que puede llevar a que ideas como la de la erradicación se deslicen de "la pobreza" a "los pobres" o del "trabajo infantil” a los “trabajadores infantiles”. Y esto es marcado por los entrevistados cuando señalan: "la alternativa era la erradicación... totalmente mentirosa la propuesta de erradicación, porque eran gracias que se hacían recurrentemente, que mandaban señales a la gente, por ahí los raleaban... se veían durante un tiempo un poco menos de chicos"...(funcionario Municipal) o "cuando vienen las vacaciones la política es sacar a los chicos pobres de Carlos Paz, digamos. Para colmo, el gobernador de Carlos Paz... era una historia en Carlos Paz en ese momento, entonces había que... Entonces nos mandaron a la noche. Yo fui, porque por ahí estas cosas me gustan, porque vos ves qué pasa (...) el programa "Disposición Padres" consiste en que la Policía levanta a los chicos, menores de 18 años, y los pone a disposición de sus padres. Los lleva a "Protección Jóvenes"... ahí se avisa a los padres; los padres los vienen a buscar y se los llevan a la casa. Previamente, se habla con los chicos y con los padres, y se les dice que sus hijos no pueden estar en la calle. Lo que el Estado dice es que ese niño vuelve a su casa y tiene que estar bajo el control de sus padres, y la responsabilidad es de ellos.” (profesional del Area Social de la Provincia).

"Y la modalidad de la institución ha sido siempre, cuando se han detectado chicos en situación de trabajo infantil en la calle, colocarlos en institutos. Y luego se trabaja, para el egreso de estos chicos”(Jefa de Area Social de la Provincia).

Todas estas expresiones están señalando un Estado que está presente, entonces, pero a través de políticas concretas especialmente diseñadas para atender la problemática desde una lógica de persecución, represión, institucionalización y depositación de la responsabilidad en las familias.

\section{Conclusiones}

La primera conclusión de este estudio señala que el contexto social, político y económico de los países estudiados ha determinado que, no obstante el compromiso internacional con la Convención Internacional de Derechos de los niños y niñas, ocurrió en períodos similares, la distancia entre texto (la política) y el contexto, es más o menos desgarradora, en la medida que la estabilidad social, la corrupción política y los sobresaltos económicos, reflejan o se distancian del gobierno de turno en cada país.

Para Argentina, las problemáticas de la infancia se convierten hoy en una de las cuestiones sociales más críticas. Las políticas neoliberales de la última década produjeron en el país ${ }^{24}$ una catástrofe social, de 10 millones de niños menores de 14 años, 4,5 millones viven en hogares situados por debajo de la línea de pobreza ${ }^{25}$. Muchas dificultades que afectan la vida de niños y adolescentes entran al campo de una situación, cuya singularidad es que deben trabajar para garantizar su subsistencia personal y muchas veces la de su familia.

En estas condiciones macroestructurales, el trabajo infantil se instaló como tema de agenda pública $\mathrm{y}$, por lo tanto, un campo de disputa en donde actores sociales toman postura, actúan y dirimen tensiones y contradicciones sociales. Tal como se

24 La Luciérnaga es una iniciativa centrada en la producción, venta y difusión de una Revista que trata temas de los niños/as adolescentes, en situación de pobreza y que los mismos chicos venden en las calles de la ciudad. Mismo ámbito público donde antes limpiaban vidrios o hacían venta callejera o pedían limosna. Esta experiencia comenzó con un trabajo de educadores de calle que posteriormente se tradujo en una organización de la sociedad civil y que alcanzó reconocimiento y legitimidad a nivel local, nacional e internacional. Aún se mantiene activa e incorporando y complejizando sus acciones.

25 Fuente: INDEC - SIEMPRO 
planteó en un comienzo, un objetivo central de esta investigación fue identificar y reconstruir las perspectivas que los actores sostienen, presuponiendo la coexistencia de miradas contradictorias y en tensión, cuyos matices son fundamentales de identificar.

Uno de los ejes más significativos que surgen del análisis que se realizó en el caso Argentino refleja el modelo de Estado, y las políticas sociales reorientadas en los ' 90 representaron un "paradigma propuesto desde los grupos técnicos con acceso a los círculos de poder (estructurados) sobre dos ideas fuerza: "focalización” y "grupos vulnerables" o de "alto riesgo" (usualmente identificados con la noción de "pobreza extrema”)" (Lo Vuolo, 1993). Estas ideas fuerza están sustentadas en un vasto material producido desde los organismos internacionales de asistencia técnica y crediticia, planteando una visión "residual" de la política social: a la política social le corresponde actuar allí donde el mercado no llega.

En el ámbito estatal de Córdoba las intervenciones concretas diseñadas para la atención de niños y jóvenes que reforzaron o en el mejor de los casos mantuvieron el paradigma de la "situación irregular”, caracterizadas por ser asistenciales y actuar ex-post, a partir de una decisión judicial que dictamina que existe el problema de abandono, riesgo social y/o moral del menor.

Pero, en tanto las instituciones no son una entelequia sino que están habitadas por sujetos, incorporar la palabra de los sujetos permite develar crítica y resistencia a estas políticas desde dentro de las instituciones públicas. En este caso, grupos de profesionales, técnicos y educadores de diversas áreas vinculadas al tema de la infancia, intentaron en estos años sostener estrategias promocionales, de prevención y de articulación en redes sociales y comunitarias, desde la perspectiva de encuadrar la problemática de los niños y jóvenes en situación de vulnerabilidad (social y de sus derechos), como expresión de un problema social a partir de la pro- ducción y reproducción de las relaciones sociales en un sistema social determinado.

A pesar de estos intentos -que tuvieron logros esporádicos, puntuales- el resultado dominante fue un proceso creciente de burocratización en la atención de la problemática; reforzando la ineficiencia, la baja calidad en sus prestaciones, la falta de integralidad de las acciones. La emergencia de prácticas discursivas cuestionadoras, pero que finalmente fueron "cooptadas", "colonizadas" -en la perspectiva que plantea Foucault- por el discurso institucionalizado que continuó "entrampado" en las “telarañas” de la asistencia- judicialización.

En este marco, se ubica la mirada del actor público estatal y una de las primeras constataciones es un modo de invisibilización que opera a nivel de las instituciones públicas, suprimiendo la categoría "trabajador" y operando desde otras nominaciones más funcionales a la programática vigente: "niños en situación de calle", "niños encontrados en la vía pública”, "niños maltratados”, "niños abandonados” etc. La invisibilización -vía la negación de la existencia del problema- pareciera ser el mecanismo que mayor funcionalidad otorga al sistema, al posibilitar la reproducción de modos de acción institucional de larga data y funcionales a las "nuevas” perspectivas de políticas asistencialistas focalizadas.

También se encuentra en el ámbito público estatal con otros énfasis, que nombran al trabajo infantil como tal, reconociéndolo como una problemática que, si bien no es nueva, se está instalando en la agenda pública y que comienza a preocupar a la institución escolar de una manera aún no suficientemente delimitada; verificándose la inquietud e interés por comenzar a dimensionar la problemática, a fin de incluirla como tema, sin una necesaria y previa significación negativa y planteándose interrogantes que hablarían de una apertura y de búsqueda de respuestas políticas e institucionales adecuadas a la realidad del niño. 
Más allá de la pertenencia al ámbito provincial o municipal, es de destacar el peso que tiene en el discurso de los funcionarios entrevistados (o sea, que están designados desde el partido que gobierna) el reconocimiento acerca de: que las cosas no se hacen bien, que las decisiones no son las correctas o las mejores, que no se sabe o no se conoce cómo actuar. En síntesis, una gran debilidad conceptual y de posicionamiento en quienes tienen la responsabilidad de definir y conducir políticas del estado.

Un rasgo dominante en las Políticas Sociales es una tendencia a caracterizar los comportamientos o estrategias familiares como algo ya instalado, como un dato naturalizado y que caracteriza "per se" a un tipo de familia, sin poder reconocer que -en primer término- la reproducción de estas estrategias familiares es consecuencia de la lógica focalizada y asistencialista de las Políticas Sociales predominantes en los últimos años, que instaló la fragmentación en el abordaje del problema y lo atendió desde la idea de provisión de los recursos con una lógica desarticulada y netamente clientelar. Invertir los términos de la explicación sobre un problema, tiene consecuencias graves tanto en la comprensión como en el diseño y abordaje de estrategias de intervención, y en este caso, podemos resaltar un modo más de fortalecer un histórico problema en las políticas sociales dirigidas a la pobreza: la culpabilización de la víctima.

Otra expresión más de la tendencia anterior es la valoración negativa de las familias que no tendrían o habrían perdido los valores y las prácticas de cuidado y protección de sus hijos/as. Ello se expresa en el surgimiento y sostenimiento -en la actualidad- de Programas de Políticas Sociales que contemplan un aporte económico a la familia vinculado a una contraprestación que contempla por ejemplo el cuidado de la salud y la educación de los niños/as. Ello, además, conlleva una mirada de los niños/as lejana a la perspectiva de sujetos de derecho, y los ubica como elemento de control para garantizar la permanencia o no de su familia en el Programa a partir de la asistencia educativa y de salud que el mismo reciba.
Las políticas focalizadas, asistencialistas y clientelares; la búsqueda de rédito político a través de estrategias de propaganda, como así también la desarticulación entre las diferentes áreas que abordan el problema, lejos de constituir una respuesta real del Estado a través de Políticas Sociales, abren el espacio para que surjan otro tipo de intervenciones, las políticas ligadas a la seguridad- represión.

Esta combinación de perspectivas favorece la reproducción social del paradigma de la situación irregular en las instituciones y las prácticas sociales, oculta el verdadero problema y favorecen la lógica de traspasar el mismo a las estrategias de judicialización de la pobreza y la represión policial.

Con respecto a la Política educativa, se puede remarcar el problema relativo a que la escuela -predominantemente-se presenta como un mundo extraño a la vida cotidiana del niño/a trabajador, no se predispone para ir a su encuentro, sino que se instala en un espacio material y simbólico de autoridad inamovible y es el niño trabajador el que debe adaptarse a ella. Esta perspectiva lleva a situaciones concretas tales como: un programa que no contempla sus saberes, una cultura escolar que nada tiene que ver con la suya familiar, prácticas que no puede aprehender ni asumir porque le resultan ajenas y descalificatorias, propuestas que no contemplan sus intereses y expectativas.

Comúnmente, se presenta el trabajo infantil en una doble asociación: trabajo infantil y deserción/ fracaso escolar, trabajo infantil/pobreza. En ambos casos, la asociación termina interpretándose como relación causal (trabajo infantil = causa de pobreza y deserción escolar). Los términos aparecen asociados en una fuerte correlación (esto es lo que da permiso a atribuir la causalidad). Sin embargo, no llega a describirse o demostrarse como interactúan. Es importante señalar que concurrencia no significa determinación y no llega a demostrarse como interactúan en este supuesto proceso gestatorio. La presencia simultánea de los tres fenómenos no esta indicando dependencia de una variable de la otra, 
ni tampoco cual de ellas es la causante de la existencia de las demás. Esta insuficiencia probatoria nos exige poner en cuestión estas afirmaciones, que por estar fuertemente instaladas en el imaginario de los adultos a que hacemos referencia, parecieran no necesitar confirmación. Esta falta de interrogantes o de intentos de profundización en la complejidad de la relación planteada nos estaría expresando otro a priori que lejos de complejizar y ampliar la lectura, simplifica y naturaliza, lo que conlleva el peligro de reforzando las miradas estigmatizantes.

Las dificultades mencionadas se vinculan con la formación docente, donde predomina la enseñanza de contenidos que hablan de una infancia armónica, de un niño/a abstracto, de un modelo de cultura tipo -la occidental desarrollada-. Todo ello no aporta las herramientas necesarias al maestro que debe relacionarse con niños/as de distinto género, clase, etnia, habitante de zona rural o urbana, religión, etc.

La diversidad de vivencias familiares y comunitarias aún debe ser objeto de investigaciones sociológicas y antropológicas que dan cuente de ella. Esta debilidad teórica y de formación influye en que las maestras, que en la mayoría de las escuelas rurales y urbano marginales provienen de otro sector social, intenten confirmar el propio modelo educativo, reproduciendo discriminaciones instaladas socialmente y en la organización escolar: de clase, de género, de generación. La experiencia de largos años de trabajo social y educativo con las escuelas nos indica que son pocos los docentes que logran superar todos estos obstáculos y producir un ensamblaje de su enseñanza y sus prácticas escolares con la realidad de los niños trabajadores.

Para finalizar el análisis del caso argentino, es fundamental remarcar que una sociedad con grandes diferencias sociales, con una creciente dualización social que cambió su estructura social en los últimos 30 años y un escenario de políticas sociales como el descrito -o sea contextos político institucionales democráticos pero con débiles garantías de los derechos sociales y económicos- es una mala combinación que puede llevar a que ideas como la de la erradicación se deslicen de "la pobreza" a "los pobres" o del "trabajo infantil” a los "trabajadores infantiles”.

La infancia como institución social es un constructo contingente y las concepciones acerca de ella son históricas. Entonces, los interrogantes sobre ciertas certezas son fundamentales para no crear falsas dicotomías. Si el trabajo es un anti-valor o una patología, ¿cómo hacemos para rescatarlo en la edad adulta como dimensión de la inserción social? ¿Cómo logramos no contradecirnos al enseñar los derechos laborales y las posibilidades creativas y no sólo productivistas del trabajo humano? ¿Cómo les ayudamos a defenderse de los daños de la explotación, la nocividad o la alineación del trabajo en una sociedad injusta y excluyente? Si negamos la elección o la cotidianeidad del niño, ¿Cómo hace la educación para aportar aprendizajes constructivos y constitutivos de la identidad en su mundo de la vida?

Sólo a título de ejemplos estos interrogantes nos muestran la posibilidad de deslizamientos semánticos e ideológicos que reclaman nuestra sobre los saberes institucionalizados y a los saberes sojuzgados, remitiéndonos permanentemente a la mirada crítica e histórica de las luchas de poder en las que estamos inmersos.

En el caso chileno, si bien se establecen aspectos conclusivos muy específicos a la política de reducción del trabajo infantil, tales como los que se señalan más abajo, existen algunas similitudes con el caso argentino, las que se expondrán al finalizar este estudio.

Si consideramos que el Trabajo infantil en sus peores formas y, dentro de él, la explotación sexual comercial infantil antes del año 2001 no contaba con suficiente sustrato conceptual que permitiera abordar el fenómeno, limitándose básicamente a definiciones operacionales que clasificaban los distintos tipos de trabajo infantil. Si consideramos, además, que hasta entonces los esfuerzos de su

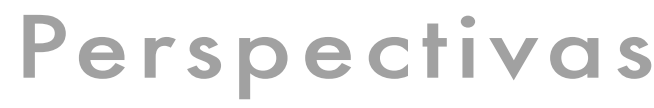


medición tendían a constituirse a través de datos discontinuos, y categorías heterogéneas, limitando la entrega de información más rigurosa sobre este fenómeno. Y que así todo, existía alguna evidencia de una temprana inserción de los niños, niñas y adolescentes en las actividades laborales más evidentes, y una velada presencia de actividades de carácter ilegal e informal, difícilmente detectables a través de mediciones convencionales.

Por último, si consideramos la existencia de escasas intervenciones relevantes en el abordaje de la problemática, entonces y en virtud de todos los considerando previos, es claramente evidente que se ha avanzado notablemente en el abordaje del Trabajo Infantil en estos últimos 5 años.

Lo anterior es de suma importancia, ya que las intervenciones generadas han aportado conocimiento relevante sobre un fenómeno desconocido, la reflexión sobre la intervención ha sido permanente, y se han detectado componentes centrales de los modelos de intervención:

- En el caso de trabajo peligroso, es fundamental privilegiar el eje en la educación asegurando retención y éxito escolar, e interviniendo estratégicamente el sistema escolar que resulta altamente resistente. Por lo anterior es esencial sensibilizar y flexibilizar este sistema, convirtiéndolo en una institución escolar que privilegia la heterogeneidad y aprende a formar en la diversidad, aceptando distintas historias en la vida de los niños/as. Un sistema que privilegia la homogeneidad en la población que atiende, está condenado a convertirse en un órgano expulsor de la diferencia.

- $\quad$ Es relevante también, generar estrategias para sensibilizar a nuevos actores con el tema del trabajo infantil y dentro de éste, las peores formas.

- Las prácticas desarrolladas requieren buscar referentes conceptuales que permitan "NOMBRAR” las formas de intervención, poten- ciando de esta manera la capacidad de generar conocimiento sobre los fenómenos sociales y de replicar intervenciones exitosas.

- La asociatividad y construcción de redes es un componente esencial, especialmente para la intervención en ESCI donde la opción inductiva para la generación de modelos de intervención requiere una permanente revisión del modelo, para lo cual la existencia de redes asegura la existencia de un espacio donde socializar conocimiento acumulado.

- Para evaluar la intervención en ESCI, es fundamental revalorar indicadores de éxito asociados a los procesos, pues son indicadores de éste tipo los que dan cuenta sobre la dignificación de la vida de los NNA que han sido vulnerados por este fenómeno, es fundamental reconsiderar los tiempos de intervención considerando el tiempo suficiente requerido para la reparación.

- La continua reflexión sobre las prácticas y los hallazgos permite a los implementadores de las políticas sociales participar efectivamente en el diseño y reformulación de las de las mismas, asegurando un permanente vínculo entre el texto y el contexto, desafío permanente de la política social.

No obstante todos estos logros y aprendizajes generados a la luz de los programas diseñados para enfrentar el Trabajo Infantil, se evidencian algunos nudos similares difícil de superar en ambos países, si no es a través de un cambio cultural de largo plazo.

Estos nudos se pueden nombrar de la siguiente forma:

- Resabios del paradigma de la irregularidad social que todavía establece como disfuncional la situación de diferencia, cuando ésta escapa a la norma social. De este modo, se mantienen relaciones causales que desdibujan una reali- 
dad compleja y multicausal. Estas relaciones causales son muy claras a la hora de establecer culpables:

- las familias son las principales responsables del trabajo infantil

- es el trabajo infantil el que produce deserción escolar, retraso o mal rendimiento (una relación incluso factible de ser invertida)

- Invisivilización de un contexto económico que conduce a contextos desiguales que fuerzan situaciones de vulneración que no pueden ser revertidas en su totalidad si no se atiende ese contexto más amplio

- Instituciones, profesionales y sujetos de intervención permeados por una lógica de irregularidad social, donde el tránsito hacia una perspectiva de derecho exige necesariamente superar la pura transformación del discurso oficial, y el compromiso con los organismos internacionales a través convenios y tratados. Nuestros países requieren hacer carne la perspectiva de derecho, invirtiendo en acciones que escuchen a los afectados, en intervenciones que superen las comprensiones dicotómicas de la realidad, en profesionales

\section{BIBLIOGRAFÍA}

ARENDT, H.(1993); La condición humana, R. Gil Novales (trad.), Barcelona

ARENDT, H.(2002); "La vida del espíritu”, F. Birulés \& C.Corral (trad.), Barcelona, 2002 [The Life of the Mind. Nueva York: M. McCarthy (ed.), 1978].

AILLÓN SORIA, S.(2002-2003); "Entre el yo compartido y el yo estigmatizado”. En: Dialogando. Cochabamba-Bolivia: Terre des Hommes.

BERMUDA, J. M. (2001) (a): Filosofía política. I: Luces y sombras de la ciudad, Barcelona.

BERGER, P \& HEFNER.R Spiritual Capital, in comparative perspective. Institute for the Study of Economic Cultura, Boston University.

BETTONI, A; CRUZ A; (2002) "Voluntariado en América del Sur: perfiles, impacto y desafíos". V Conferencia Internacional de la Sociedad Internacional de Investigación del Tercer Sector capacitados para comprender, conceptualizar y transformar lo social.

- En este sentido, importa recoger lo planteado por el paradigma de la promoción social de la infancia que propone la constitución de otra cultura de la infancia transforme el adultismo y la cultura del adulto a partir de una reivindicación histórica generacional, de género y de clase.

- Asimismo se propone ampliar la mirada sobre los diversos niveles en los que se ejerce el trabajo infantil, superando visiones de blanco y negro, que definen absolutamente bueno o absolutamente mal el trabajo infantil. Es necesario permear la política de estos dos países hacia la valoración del derecho universal y el valor humanizador del trabajo, en la subjetividad de cada cual y como mecanismo de integración social. Incorporar así mismo una mirada crítica la carácter explotador que muchas veces el trabajo infantil posee, tornándose en ocasiones en causa de vulneraciones atroces en niños y niñas.

- $\quad$ En este último sentido, es justamente una perspectiva crítica la que permite recuperar el carácter ético y potenciador de la actividad humana.

(ISTR) 7-10 de julio de 2002 - Ciudad del Cabo, Sudáfrica Instituto de Comunicación y Desarrollo Montevideo - Uruguay

BOURDIEU, P.(1988); Cosas dichas. Gedisa

BERGER P., LUCKMANN T.(1993); La construcción social de la realidad. Amorrortu editores

BOURDIEU, P.(1991) El sentido práctico. Taurus, Madrid

BRONDI ZAVALA, M. (2001) "Niño familia y comunidad en los Andes” En: Culturas e Infancia. Lima, Terre des Hommes, Germany

BUSTELO, Eduardo (1998); “Expansión de la ciudadanía y construcción democrática”, en Todos entran: propuesta para sociedades incluyentes, UNICEF- Grupo Santillana, Bs. As., 1998.

CASELET, D; 2006; Convocatoria para el concurso Proyecto de Financiamiento sobre Economía del Conocimiento, México D.F Ambos Medios Junio 17, 2006

CASTEL, R.(1997); Las metamorfosis de la cuestión social. Una crónica del salariado. Editorial Paidos Estado y Sociedad. 
CUSSIÁNOVICH VILLARÁN (2001); “Nacer pobre y crecer pobre”. En Castro Morales, Jorge; Niñas, Niños y Adolescentes: Exclusión y Desarrollo Psicosocial. Tomo I. Lima: IFEJANT.

CHAPP,M. Juventud y familia en una sociedad en crisis. Bs. As. Centro Editor de América Latina

FINKE, R; Spiritual Capital: Definitions, Applications, and New Frontiers (2003) Prepared for the Spiritual Capital Planning Meeting October 2003

FOUCALT, M.(1992); Microfísica del poder, Ediciones La Piqueta, $3^{\circ}$ ed., Madrid

FREIRE, P.(1988); La educación de calle. MEDH. 1988

GÓMEZ DA COSTA, A.(1998); “Educación por el trabajo”. Ponencia presentada al Congreso de Mar del Plata Julio

GUNNARSSON, V; ORAZEM, P; SÁNCHEZ M. (2006) "Child Labor and School Achievement in Latin America The World Bank Economic Review, vol. 20, №.1 pp. 31-54

GUTIÉRREZ, A. (1994); Pierre Bourdieu: las prácticas sociales. Buenos Aires. Centro Editor de América Latina. http://www. ecpat-esp.org/esci/causas.htm

HETHERINGTON, K; (1996), "Identity formation, space and social centrality" Theory, Culture and society Volume 13 (4):33-52

HEADY, (2003) The Effect of Child Labor on Learning Achievement University of Bath and Organisation for Economic Co-operation and Development, Paris, France. World Development Volume 31, Issue 2, February. Pp. 385-398

IFEJANT (1997) Autores varios. Niños Trabajadores Protagonismo y actoría social. Perú. 1997

INE (2003); Encuesta Nacional sobre actividades de niños y adolescentes en Chile, aplicada entre febrero y abril del 2003 http://www.trabajoinfantil.cl/

Ministerio del Trabajo (2001); Plan de Prevención y Erradicación Progresiva del Trabajo Infantil y Adolescente en Chile. Gobierno de Chile.

KOTLIARENCO, M., CÁCERES I. y ALVAREZ, C.(1996); Resiliencia. Construyendo en la adversidad CEANIN. Santiago de Chile.
LASALA M.: "Los límites de la ciencia y la ciencia como límite”, en Fair, Lasala, Regnasco,

LO VUOLO; R.(1993); “¿Una nueva oscuridad? Estado de Bienestar, crisis de integración social y democracia”, en La nueva oscuridad de la política social, Editorial Ciepp/Miño y Dávila, Bs. As.

Ministerio del Trabajo (2003); Trabajo Infantil y Adolescente, Diagnóstico Nacional, Resumen Ejecutivo. Gobierno de Chile

Programa AURA (2004); Informe Final de Resultados. Información General sobre el Programa de Acción y de la Agencia ejecutora

QUIROGA, Ana (1990); Crítica de la Vida Cotidiana. Ediciones cinco, Bs, As.

RAICES (2003) Informe Final Proyecto Piloto, Sistematización, Proyecto $\mathrm{N}^{\circ} 130193$ "Estrategia Integral de Intervención para la Reparación del Daño Sufrido por Víctimas de Explotación y Comercio Sexual Infantil” Santiago

RODRÍGUEZ, M. H.(2004-2005); “Sociedad e infancia en los Andes”. En: Dialogando, Cochabamba-Bolivia, Terre des Hommes.

ROIZ, J.(1993); La recuperación del buen juicio. Teoría política en el siglo veinte, Madrid, 1993.

ROJAS, Jorge (2000); "El Trabajo Infantil en Chile: Algunas Ideas para el Debate”. En: Trabajo Infantil Freno al Desarrollo, Panorama general de políticas para su erradicación de en Ministerio del Trabajo, UNICEF.

Trevijano. (1991); La razón científica su texto y su contexto. Edit. Biblos. Buenos Aires

SCHIBOTTO, G. (1997); La Acción Social con JANTs. Modelos interpretativos IFEJANT; Lima. Perú

VOLPI, F. (1995); Hermenéutica y filosofía práctica, Éndoxa. Series Filosóficas.

UNICEF (2005) Situación de los niños y niñas de Chile. A 15 años de la ratificación de la Convención sobre los Derechos del Niño 1990-2005. Santiago Chile. 